Grand Valley State University

ScholarWorks@GVSU

\title{
The unbearable heaviness of leadership: The effects of competency, negatives, and experience on women's aspirations to leadership
}

\author{
Carol M. Sanchez \\ Grand Valley State University, sanchezc@gvsu.edu \\ Kevin Lehnert \\ Grand Valley State University, lehnertk@gvsu.edu
}

Follow this and additional works at: https://scholarworks.gvsu.edu/mgt_articles

Part of the Business Administration, Management, and Operations Commons

\section{ScholarWorks Citation}

Sanchez, Carol M. and Lehnert, Kevin, "The unbearable heaviness of leadership: The effects of competency, negatives, and experience on women's aspirations to leadership" (2019). Peer Reviewed Articles. 41.

https://scholarworks.gvsu.edu/mgt_articles/41

This Article is brought to you for free and open access by the Management Department at ScholarWorks@GVSU. It has been accepted for inclusion in Peer Reviewed Articles by an authorized administrator of ScholarWorks@GVSU.

For more information, please contact scholarworks@gvsu.edu. 


\title{
The Unbearable Heaviness of Leadership: The Effects of Competency, Negatives, and Experience on Women's Aspirations to Leadership
}

\section{Carol Sanchez \\ Kevin Lehnert}

Journal of Business Research, 2019

\begin{abstract}
Competent women should aspire to leadership, but they may choose not to. We asked men and women at seven U.S. universities if competence, negatives of leadership, and experience affect their aspirations to leadership. Surprisingly, competent women with more work experience are less likely to aspire to leadership than men, while competent women with less work experience are more likely to aspire to leadership than men. The more women associate leadership with negative aspects, the less they aspire to leadership, compared with men. For both, the less competent they think they are to be leaders, the less they want to be leaders.
\end{abstract}

Keywords: Gender, Leadership, Stereotype, Career socialization, Sex discrimination 


\section{The Unbearable Heaviness of Leadership: The Effects of Competency, Negatives, and Experience on Women's Aspirations to Leadership}

\section{Introduction}

Thousands of outstanding women have achieved great things leading organizations and nations. Notable women leaders include Prime Minister Indira Gandhi and Chancellor Angela Merkel in politics, Esteé Lauder and Indra Nooyi in business, Queen Cleopatra VII and Queen Elizabeth II in the monarchy, Dr. Alice Palmer and Dr. Drew Gilpen Faust, presidents of Wellesley College and Harvard University respectively in academia. Women are successful leaders. But despite the history, fewer women than men hold top leadership positions in politics, business, and academia (Lennon, 2013). Is it possible that women often choose not to seek top leadership positions?

While women hold over $40 \%$ of the managerial positions in the U.S. (Eagly \& Carli, 2007), they often remain in positions of middle management at best, or in even less influential positions, such as support staff or assistants. Not that having a female assistant is unusual: people reach for their mobile devices and say "Hey Siri" or "Hey Cortana" and await these virtual assistants, who are female in most cases, to help solve problems. Some smart phone experts argue that it is easier to find a female voice that everyone likes rather than a male voice (Nass \& Yen, 2010). Others argue that people expect women, not men, to serve in support roles - and that the makers of digital assistants are influenced by these social expectations (Lafrance, 2016).

Why are there significantly more women in positions of less authority, and so few in upper leadership positions? We argue that many competent and experienced women make a conscious decision to not aspire to top leadership positions. Despite being encouraged to "lean in" (Sandberg \& Scovell, 2013), many able and experienced women may choose not to aspire to 
top leadership. According to the U.S. Equal Employment Opportunity Commission, outright sex discrimination is but one barrier to women attaining leadership roles (U.S. EEOC, 2017b). There are also other elusive problems that discourage women from pursuing the top spots, such as hostile work environments, negative stereotypes, and bias (Moor et al., 2015). In this paper, we examine new ideas that may explain what drives women to aspire, or perhaps to not aspire, to leadership roles. We argue that there are differences between men and women's attitudes about their respective competencies, experience, and personal aspirations to leadership. We investigate women's aspirations to leadership in American higher education, and suggest results that may help us understand why women are underrepresented as leaders in other types of organizations as well.

This paper does what few papers on gender diversity in leadership do: it examines a sample of both men's and women's aspirations to leadership based on individual, institutional and social factors. We surveyed 1,700 male and female faculty and staff working at seven U.S. colleges and universities to examine if they aspire, or not, to leadership positions for which they think they are competent. Then we asked them if they perceived themselves as competent to lead, about their work experience, and about the positive and negative attributes of leadership. Findings suggest that, compared with men, women's aspirations to leadership depend on how competent they think they are, how negatively they perceive the tradeoffs of leadership to be, and how much experience they have.

Among people who believe they are highly competent to be leaders, we found that women with less work experience are more likely to aspire to leadership, compared with men. Most interestingly, women with more work experience are less likely to aspire to leadership, compared with men. Further, the more women associate leadership with negative aspects, the 
less likely they want to be leaders; whereas men aspire to leadership regardless of whether negative aspects are high or low. Finally, for both men and women, the less competent they think they are to be leaders, the less they want to lead. In the next several pages, we review the literature that underpins our hypotheses, explain our methods and results, and discuss our findings that women's leadership potential is untapped in higher education, in part due to women's perceptions about their competencies, their experience, and the leadership positions.

\subsection{Untapped potential: The lack of women in leadership positions}

Business organizations in the United States generally lack diversity and inclusion in leadership, even though the topic gets frequent nods and lip service in annual reports, SEC filings and organizational websites (Barclay et al., 2017). For example, only twelve of Fortune's top 500 companies also appeared on their 50 Best Workplaces for Diversity list, and 400 of the top 500 do not share data about the gender or ethnicity of their employees (Donnelly, 2017). Still, diversity should be important to organizations for many reasons. Diversity reflects the population of most organizations' constituents, clients, and customers, compelling people to tackle ideas in different ways. Diversity brings the organization knowled ge about many types of people, and offers counsel from diverse authorities. Diverse leadership sets an example at the top, has a trickle-down effect on the rest of the organization, and it makes the organization more adaptable to its environment (Lennon, 2013; Leon \& Jackson, 2009; Myatt, 2013). Firms with more diversity see over twice the cash flow per employee than their less diverse peers (Donnelly, 2017). Firms with greater gender diversity in top management teams show lower risk and better performance (Perryman et al., 2016) and those with racial diversity are more likely to have larger returns (Hunt et al., 2015). 
Regarding gender diversity, women make up $47 \%$ of the U.S. labor force, hold over $40 \%$ of managerial jobs, and earn the most associates, bachelors and advanced degrees. However, women hold fewer than $20 \%$ of top leadership jobs in organizations (Lennon, 2013). Among the top 100 companies in the state of Michigan, for example, there has been scant progress to increase the number of women leaders in recent years. Fewer women hold executive officer positions in 2017 than in 2007 (76 versus 88). Women's 13\% share, unchanged since 2015, has barely budged from $12 \%$ a decade ago (Barclay et al., 2017). Some good news is that women's share of board seats on Michigan companies increased - from 10\% in 2007 to 15\% in 2017. While improved, in Michigan corporate board compositions is still skewed with an 85:15 ratio of men to women (Barclay et al., 2017).

Women's representation at the highest levels of corporate management is also persistently low in the rest of the U.S., and internationally. What's more, women on average earn less than men in comparable jobs while, by some measures, outperforming them (Hegewisch \& DuMonthier, 2016, O’Connor, 2013). After adjusting for age, education, experience and other variables, there is a pay gap between women and men. The median salary for women working full-time is about $80 \%$ of men's, meaning that women are working for free about ten weeks a year (G.V., 2017).

In academia, the situation is similar. Women are underrepresented in leadership positions in U.S. colleges and universities, despite their high numbers in overall faculty and staff positions. In 2014, 43\% of faculty in U.S. higher education institutions were women, and 57\% were men (Johnson, 2016). But only about one-third of full professor positions were held by women, a little more than one-fourth of college presidents were women, and just over one-third of chief academic officers were women (Johnson, 2016). Women hold fewer than 25\% of leadership 
positions, and although some universities have hired more women and minorities, their percentage in leadership is still very low (Lapin \& Sullivan, 2014). Even fewer women of color hold full professorships compared to others, and women earn $20 \%$ less than their male counterparts at U.S. universities (Lennon, 2013).

Women earned more than half of all bachelors', masters', and doctoral degrees since 1981, 1991, and 2006 respectively (Johnson, 2016), but this achievement does not translate into higher education leadership, specifically positions with budget authority and oversight, personnel appointing authority, and discretion over major decisions that impact the units they lead. This is nothing new: Konrad \& Pfeffer(1991) found that women and minorities are less likely to be hired into positions of leadership in higher education, and if they are, they assume lower level positions.

\subsection{Why are women untapped for leadership positions?}

Studies tend to attribute three broad explanations for the underrepresentation of women in leadership: gender stereotypes (Athitakis, 2013; Caprino, 2013; Eagly \& Karau, 2002), different career socialization (Hoobler, Lemmon \& Wayne, 2014), and sex discrimination in the organization (Hale, 2009; Moya, Glick, Expósito, DeLemus \& Hart, 2007). Only a few studies (e.g., Hoobler et al., 2014) have examined how variables within these three types of barriers affect women and men differently. Our study does this. We argue that because of these barriers, men and women perceive their competencies, the negatives of leadership, and their experience differently, which helps explain why so few women are in American higher education leadership. Below, we discuss key factors underpinning these three explanations, and hypothesize several relationships that try to explain why women are underrepresented in leadership. The models are depicted in Figures 1 and 2. 


\section{Figures 1 and 2 here}

\subsubsection{Persistent gender stereotypes and perceptions of leadership competency}

Stereotypes, or cognitive "shortcuts" that categorize people based on characteristics such as gender, race, or age (Crites et al., 2015), prevent women from occupying more leadership positions (Spencer, Steele \& Quinn, 1999; Steele, 1997. Stereotypes backfire when employers and peers apply it to a work setting (Heilman, 2012; Eagly \& Carli, 2007), because it biases how decisions concerning women are made. For example, stereotypes about women as mothers can negatively affect women pursuing leadership roles if employers assume that women's caregiving commitments make them less competent for demanding jobs. This stereotype portrays women as nurturers and less competent to be leaders as they cannot make hard decisions that may affect stakeholders. Williams \& Cooper (2004) note that "motherhood triggers powerful negative competence and commitment assumptions" that can result in a "maternal wall" of bias. The fatherhood stereotype seems to have the opposite effect: after becoming fathers, men see about a $6 \%$ increase in earnings after controlling for factors such as hours worked and marital status. New mothers see a $4 \%$ decrease per child (Budig, 2014). Some working women hit the maternal wall before they hit the glass ceiling. Pregnancy discrimination can start as soon as a woman is showing, and it may last through her early years as a mother. There seems to be a pattern: many US companies systematically sideline pregnant women, pass them over for promotions and raises, and fire them when they complain (Kitroeff \& Silver-Greenberg, 2018). Pregnant women and mothers are often steered away from prestigious assignments, excluded from client meetings and slighted at bonus season. Highly skilled women who earn high wages are penalized most, partly due to their lost experience. This means that even when women take small periods of leave for childrearing, they pay a high price (England, Bearak, Budig \& Hodges, 2016). 
A related stereotype is that women choose to raise a family over working and leading. While balancing work and family responsibilities is challenging for every leader (Eagly \& Carli, 2007; Sandberg \& Scovell, 2013), the fact is that women are more likely than men to do the balancing. Women tend to be the main caregivers for children during their peak years in the workforce, they are more likely than men to work irregularly, to spend time out of the workforce (Hegewisch \& Hartmann, 2014), to work part time, and to take more time off for family (U.S. Bureau of Labor Statistics, 2017). But this makes sense: if a working woman gives birth, she is significantly more likely to quit her job if all she has is unpaid leave, than if she has paid leave (Laughlin, 2013) -and only $12 \%$ of U.S. private sector workers have paid family leave (U.S. Department of Labor, 2017). Only five U.S. states provide even temporary paid disability leave to women who give birth. So when faced with the prospect of unpaid leave or no leave at all, many new mothers feel they have little choice, and they quit working (U.S. Department of Labor, 2017).

Still, many women continue their careers very successfully, such that $70 \%$ of women with children under 18 participate in the labor force, with over $75 \%$ employed full-time (U.S. Department of Labor, 2017). Mothers are the primary or sole earners for $40 \%$ of households with children under 18 today, compared with $11 \%$ in 1960 . Nevertheless, there are those who stereotype women with young children as unreliable, and less competent because they are not on a "fast track." This unfairly excludes competent women from leadership opportunities. This "family choice" stereotype is exacerbated by differences in women's and men's earnings. When two parents work, and one has an option to reduce or leave employment, the higher-paid spouse will tend to keep working, and that spouse is usually a man. The choice has nothing to do with who is more competent: it has to do with income. In 2013, among married opposite-sex couples in which both spouses were wage earners, husbands earned more than wives $71 \%$ of the time 
(U.S. Bureau of Labor Statistics, 2017). Regardless of competency, men were less likely to cite pressure to forgo work-life benefits as a reason for leaving their job (Deutsch \& Yao, 2014). As such, both women and men are forced to make these choices in the context of cultural expectations, gender socialization, and financial constraints.

People may not easily admit to applying gender stereotypes to their attributions about the relative competencies of men and women, but stereotypes persist: a recent meta-analysis of gender and leader stereotypes found "no evidence of decreased stereotyping over time" (Koenig et al., 2011). Indeed, role incongruity theory suggests that the mismatch between the female gender role and leadership roles leads some to perceive women less favorably than men as leaders, to evaluate typical leadership behavior less favorably when women exhibit it (Eagly, Makhijani \& Klonsky, 1992), and to exhibit less positive attitudes toward female compared with male leaders (Eagly \& Karau, 2002).

Eccles (1987) noted that there are "good theoretical reasons" (p. 145) that gender socialization may lead women to underestimate their abilities than men. Because women are typically stereotyped as less competent than men, gender stereotypes may lead girls to underestimate their general intellectual abilities more than boys (Parsons, Ruble, Hodges, \& Small, 1976), which could lead them to have lower expectations of their abilities in future activities. In one experiment, women did as well as men on a science quiz, yet they thought they had done worse than men, underestimating their abilities. Later, women were less likely than men to join a science competition for fun and prizes. This reluctance correlated significantly with their perceptions of performance on the quiz, but not with actual performance (Ehrlinger \& Dunning, 2003). How competent they perceived themselves to be influenced their decision about future activities. For these reasons, we argue that people's perceptions of how competent they are 
to do a leadership job will influence whether or not they aspire to a leadership job (Fritz \& van Knippenberg, 2017), and we argue that gender moderates this relationship, as men are often very confident about their competencies, while women are frequently under confident about them (Ehrlinger \& Dunning, 2003). Women are less likely to aspire to leadership if they perceive their competencies are not high enough for the job. Men, on the other hand, are less concerned about whether or not they have all the competencies to do a job, and they are more likely to aspire regardless of their perceptions of their competencies.

H1: The less competent people, regardless of gender, perceive themselves to be for a job, the less likely they are to aspire to a leadership position.

H2: The less competent women perceive themselves to be for a job, the less likely they are to aspire to a leadership position, compared with men with similar perceptions of competence.

\subsubsection{Career socialization and negatives of leadership}

Women are only slightly less likely to participate in the workforce today than men (U.S. Bureau of Labor Statistics, 2017). For people born prior to 1955, women's workforce participation was low during their prime parenting years, reaching a peak when they were 45-50 years old. Generation X and Generation Y women were more likely to work through their prime parenting years (Hegewisch \& Hartmann, 2014; Hegewisch \& DuMonthier, 2016), and consequently have longer job tenures than women who preceded them, more closely resembling the careers of men.

But although professional women's tenures at work resemble men's, and although professional women tend to be equally qualified as men, women are socialized into their careers 
differently than men. This prevents more women from pursuing leadership, despite dramatic changes in women's educational attainment and workforce participation that gave millions of women the background and skills they need to become leaders, and provided organizations with a larger and more diverse talent pool. In other words, competent and ambitious women are not in short supply. Many of these women are experienced professionals with long tenures in the workforce, but they are socialized into their careers differently than men (Fitzsimmons, Callan, \& Paulsen, 2014) and this discourages them from pursuing leadership. Indeed, Hoobler et al. (2014) found that the lack of women in leadership is a result of women not getting the opportunities, encouragement and critical organizational development needed to aspire to higher positions.

Networking and mentoring are two career socialization paths that are different for women and men. Access to networks helps one move up the leadership hierarchy, and studies show that the social capital gained from networking with influential leaders affect advancement as much as (Peus et al., 2015) or more than job performance (Eagly \& Carli, 2007; Fitzsimmons, Callan, \& Paulsen, 2014). Although women and men are equally likely to have mentors, married women may be less likely to have a mentor compared to single women or men (Ramaswami et al., 2014), and women may benefit less from mentoring relationships, especially as they affect salary and promotions. For example, women note that many men are not interested in mentoring women (Ashford, 2017). Compared with white men, women (and men of color) have less access to networks that provide insight about jobs, promotions, professional advice, and expertise (Milkman et al., 2015). And while white women may live in the same neighborhoods, send their children to the same schools, and participate in the same community organizations as the powerful men in their workplace, it is still harder for them to network. Women of color find it 
even harder to find mentors, and their lives outside of work are unlikely to overlap with those of male managers, who tend to be white (Ashford, 2017).

For women, and especially women of color, networking often requires greater effort than for men. Networking often occurs around "masculine" activities such as golf or hunting, and because relatively few women golf, and fewer hunt, women, especially those with traditional family responsibilities, find it hard to build professional networks with colleagues outside of work. Preparing for leadership by building a professional network, seeking a mentor, joining civic and professional groups is just as time consuming, and may discourage women from pursuing that route.

Leadership is time consuming and requires great effort, leaving little room for other priorities, and both men and women may consider those to be negative aspects of the job. Because of this, how negative people's perceptions about leadership and the socialization process that surrounds it, will influence whether or not they aspire to be leaders. Leadership has negative aspects such as losing work flexibility, losing personal flexibility, having less time for personal and family activities, too much work for too little reward. These negatives make it less likely that people will aspire to a leadership job. However, we argue that gender moderates the relationship between negatives of leadership and aspiration to leadership. Because of differences in career socialization, we hypothesize that women are less likely to aspire to lead the more they perceive that there are negatives to leadership, compared with men.

H3: The more people, regardless of gender, perceive that there are negatives to leadership, the less likely they are to aspire to a leadership position.

H4: The more women perceive that there are negatives to leadership, the less likely they are to 
aspire to a leadership position, compared with men with similar negative perceptions.

\subsubsection{Experience and leadership: A matter of discrimination}

Some biases against women as leaders, such as the stereotypes discussed above, are subtle. But overt — and illegal — discrimination against women in the workplace is unfortunately all too common. In 2016 , nearly 27,000 charges of sex discrimination were filed with the EEOC, about 1,000 more than the average number of charges filed annually since 1997 . More than 7,800 charges, or nearly a third, in 2016 resulted in conciliation, resolution, or settlement in favor of the person who filed the charge (U.S. EEOC, 2017a \& b). American women earn less than men in nearly every profession, as shown in an analysis of 446 occupations where women are paid less in 439 of them (U.S. Department of Labor, 2017). As such, independent of allegations, it is evident that some organizations actively engage in blatant sex discrimination.

Some sex discrimination may be considered benevolent sexism (known as BS). While expressions of BS may convey a protective and positive attitude toward women, it is driven by men's intimate interdependence on women, and is paternalistic (Ramos et al., 2016). BS is manifested in statements that suggest women should be protected and provided for by men, or that women choose to raise a family over working and leading. Benevolent or not, BS is a problem in the workplace, because it correlates positively with hostile sexism (known as HS), which justifies men's power by demeaning women's competence. BS is related to indicators of gender inequality, which can especially limit opportunities for women once they become mothers and may potentially reduce their career aspirations (England et al., 2016). 
A hostile work environment can foster hostile sexism (HS) and discrimination. Many women's experiences in business, education, and politics are profoundly affected by expressions of blatant sexual misconduct, including microaggressions, harassment, and sexual assault. Not all sexual misconduct is illegal, but frequently it is, and it is almost always discriminatory and misogynist. For example, repeated unwelcome touching, and jokes about sex or sexual identity on a daily or frequent basis constitute harassment. Promises of advancement in exchange for sexual favors is harassment. Recent ousting of powerful men credibly accused of sexual misconduct in technology, media, and entertainment suggest that outright sexual harassment is pervasive in organizations (Zarya, 2017), and that behavior discourages women from advancing into top positions in their fields. Top female college and university leaders agree, noting that microagressions, which are frequent, small, mean-spirited acts, and low-level verbal harassment that create a hostile workplace environment hold them back from leadership. These women said they received little understanding and support from colleagues, they were held to higher expectations than their male peers, such as the pressure to outperform the men, and to attend public functions more often than men (Oguntoyinbo, 2014).

Many universities have tried to increase leadership diversity (Leonard, 2013). But some employees still perceive the work environment as discriminatory. One university climate survey revealed that those who were least comfortable with the climate in their work unit were women, people of color, and LGBTQ people. Among employees who seriously considered leaving the organization based on gender identity, $22 \%$ were women (compared to $18 \%$ men). Among people who reported discriminatory employment practices, gender was also the basis for discriminatory hiring (23\%), employment-related disciplinary actions (14\%), and discriminatory practices related to promotion (18\%). Gender reported as the second highest basis $(23 \%)$ for 
people who personally experienced harassment. While only slightly higher rates of women $(12 \%)$ versus men $(10 \%)$ reported personal harassment, substantially more women $(28 \%)$ than men (10\%) believed the harassment was gender based (GVSU Climate Assessment Project, 2011).

While sexism and sex discrimination may deter women from aspiring to leadership in organizations, we argue that the length of work experience will moderate the relationships between gender and competency on aspiration, and between gender and negatives of leadership on aspiration. Women with less work experience, we believe, will be more confident in their abilities and competencies, and therefore be more likely to rise to the occasion and aspire to leadership, compared to men with less work experience and equal confidence in their competencies (Artabane et al., 2017). Women with less work experience, who tend to be younger, may be more optimistic about the playing field being level, thereby assuming that their competencies will be weighted equally that of men they compete with. Similarly, women with less work experience are more likely to overlook or not yet know about the negative aspects of leadership (Coffman \& Neuenfeldt, 2014) -- the long hours, less flexibility, more work for not enough money, that sex discrimination does not exist - and be motivated to aspire to leadership because they believe this is the path towards greater influence, recognition and reward.

On the other hand, because of prior discriminatory experience, microaggression and misconduct in the workplace, women with more work experience who think they are very competent are less likely to aspire to a leadership position than men in a similar situation. Recall that the maternal wall imposes especially high penalties on women with high levels of experience and skill, including penalties due to the experience lost due to motherhood (England et al., 2016). These experienced women may have had aspirations in their pasts, and may have 
even served as leaders. But they know the playing field is not level, and that it takes much more effort and ability for women to succeed as leaders compared with men (Chira, 2017; Hoobler et al. 2014). Women who have more work experience are very aware of the negative aspects of leadership -- long hours, less flexibility, and expressions of sexual micro-aggression and misconduct - and they will be less likely to want a leadership position. They have been there, done that, and they simply do not think it is worth it to strive for leadership positions for which they are less appreciated, must work harder, must endure misogyny, and are paid less, than men.

H5: Among women with less work experience, the more competent they perceive themselves to be for a job, the more likely they are to aspire to a leadership position compared to men.

H6: Among women with more work experience, the more competent they perceive themselves to be for a job, the less likely they are to aspire to a leadership position compared to men. H7: Among women with less work experience, the more they perceive negatives to leadership, the more likely they are to aspire to a leadership position, compared with men.

H8: Among women with more work experience, the more they perceive negatives to leadership, the less likely they are to aspire to a leadership position compared with men.

\section{Methodology}

\subsection{Participants and measures}

We surveyed faculty and staff at seven Michigan colleges and universities, and asked for their perceptions about leadership and if they aspire to a leadership position. We developed a pilot survey based on a review of prior research and instruments, meetings with university leaders, and focus groups, and implemented it at one university. Following the pilot study, we conducted the survey at the six additional higher education institutions. Universities offer a representative sample because they can provide a more equal distribution of men and women 
employees compared to organizations in other industries. Women represented $61 \%$ of all employees in U.S. educational services in 2010, the latest reported, while representing only $28 \%$ of manufacturing employees and just $40 \%$ in trade, transportation and utilities (U.S. Census Bureau, 2012). While certain university disciplines have more men than women in faculty positions, the reverse is true for others. Our descriptive data (Table 1) suggests a relatively equal gender distribution within our sample, reflecting this.

The survey was developed by one author, and included some items adapted from Jones and Palmer (2011). It contained 56 questions that asked respondents about gender stereotypes, roles, job satisfaction, relationships with colleagues, perceived self-competencies, family and professional responsibilities, mentoring, support from supervisors, leadership, hiring, and promotion opportunities. The dependent variable was whether the respondent aspired to leadership. Leadership for faculty was defined as associate and full professorships; assistant, associate and named provosts; assistant, associate and named deans; department chairs; assist ant, associate, and named directors. Leadership positions for staff were defined as assistant, associate, and named directors; assistant, associate, and named deans. People in these positions are generally responsible for budget authority and oversight, appointing personnel, and discretion over major decisions that impact their units.

We tested face validity of the survey through analysis and critiques by other researchers in the field. Control variables included respondents' age, marital status, the number of children they have, and whether they were faculty or staff at the university. The sample size from our population was 1,240 with 809 respondents identifying as female and 431 identifying as male. Due to missing response data, the sample for perceived competency was 599, with 399 respondents identifying as female, and 200 respondents identifying as male. 
We note the potential bias between faculty and staff as variables, as faculty may hold different aspirations to leadership (i.e., transition to administration; community leadership; professional organizational leadership), than staff (i.e., promotion, employee group leadership, civic leadership, to name a few). We control for this difference within the survey design by having the measurement of leadership and aspirations reflect a generalized form. Thus, each individual can apply their own aspirations and leadership goals within the survey with no a priori limitation dictated by the researcher. Statistically, we ran competing models on the main effect hypothesis $(\mathrm{H} 1-\mathrm{H} 4)$ to ascertain the validity of the faculty / staff control variable. These models showed no differences in the relationship between aspirations, competency and negatives of leadership based upon faculty or staff categorization within our main effects. There was one significant difference between the interaction of negatives of leadership and gender, where faculty were significant and staff were not. This implies that the control variable of faculty/staff is sufficient. Means, standard deviations, and correlations are shown in Table 1.

\section{Results}

Due to the binomial response of the dependent variable, we used logistic regression analysis to test the hypotheses following Hair et al. (1998). One consideration that was made is the impact of endogeneity, in which the explanatory variables are highly correlated with the residuals, indicating that potential missing variables impact the outcome. To investigate, we ran a correlation test against the predictors and the residuals per Antonakis et al. (2010). Results showed that there was little to no relationship between the two, implying the model is not impacted by internal endogeneity.

\section{Table 1 here}




\subsection{Gender, Competency and Aspirations to Leadership}

Table 2 tests the first two hypotheses relating to Perceived Competency. Model 1 reflects the influence of control variables upon our dependent variable. Model 2 on Table 2 shows the main effects of Gender $\left(\beta_{\text {Gender }}=-0.08, \mathrm{p}=\right.$ n.s. $)$ and Perceived Competency $\left(\beta_{\text {Competency }}=.41, \mathrm{p}<\right.$ .01) on Aspirations to Leadership. This supports Hypothesis 1, indicating that the less competent individuals perceive themselves, the less likely they are to have aspirations beyond their current position. Model 3 finds no support for Hypothesis 2 which posits interactive effects between gender and perceived competence $\left(\beta_{\text {genderxcompetency }}=-0.03, p=n\right.$.s. $)$. This implies that regardless of gender, it is the perceived self-competency that determines aspirations to leadership.

Table 2 here

\subsection{Gender, Negatives of Leadership and Aspiration to Leadership}

We then investigated the potential obstacles and benefits associated with leadership and their impact on employee aspirations and likelihood to apply. Table 3 looks at the role of the Negatives of Leadership finding support for Hypothesis 3, which notes that as the negatives of leadership increase, the likelihood of applying for leadership decreases (Model 2;

$\left.\beta_{\text {Negatives_Leadership }}=-.70, p<.01\right)$. Further, as indicated by model 3 , we also see an interactive

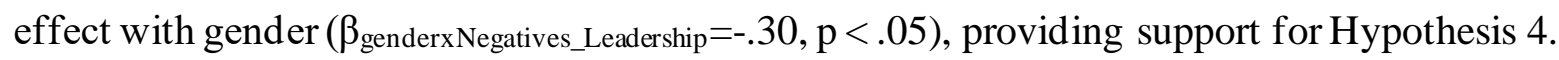
Graphing this interaction reveals that as the negatives of leadership increase there is stronger negative effect on aspirations for a leadership role for women than for men.

\section{Table 3 here}

Figure 3 here

\subsection{Gender, Work Experience and Aspiration to Leadership}


Tables 4 and 5 investigate the relationship between those employees with little work experience vs. those with more experience. We split the sample between those employees with less than 10 years' experience and those with more than 10 years' experience. Results indicated that there was a strong interactive effect between gender and competency for both employees with less experience $(G e n d e r \times$ Competency $\beta<10$ yrs experience $=.62, p<.05)$ and those with more (Gender $x$ Competency $\beta>10$ yrs experience $=-.64, p<.05$ ). Specifically for employees with less than 10 years' experience there is little influence of perceived competency on men's aspirations to leadership. However for women, as competency increases, women's aspirations also increase, where women who perceive themselves as more competent have higher aspirations to leadership than men. This implies that women are more heavily influenced by perceived competency when they have less overall work experience, and supports Hypothesis 5.

Conversely, for those employees with more than 10 years' experience, the effect switches, and we find support for Hypothesis 6 . Women are less influenced by perceptions of competency, where men who perceive themselves as more competent have higher aspirations to leadership. This effect is interesting because it may imply that for women with more experience they may believe that it does not matter how competent they are, their aspirations may already be tempered by the realities of the workplace and the barriers found within. Figures $4 \& 5$ highlight these interactions.

\section{Tables $4 \& 5$ here}

Figure $4 \& 5$ here

\subsection{Gender, Work Experience, Negatives of Leadership, and Aspiration to Leadership}

We explored the relationship between perceived negatives of leadership for employees with more or less experience. Tables 6 and 7 compares the effect of negatives of leadership 
between employees with little work experience and those with more experience. We found a strong interaction between gender and negatives of leadership for employees with less experience (Gender $x$ Negatives $\beta<10$ yrs experience $=-.54, \mathrm{p}<.05$ ), providing support for Hypothesis 7. Women with less than 10 years' experience are less influenced by negative aspects of leadership than men are, and are more likely to aspire to leadership. But as these negatives increase, women's aspirations to leadership decrease at a greater rate than men's. This suggests that while women's aspirations are more heavily influenced by negatives of leadership when they have less overall work experience, if those negatives seem to be fewer or less onerous, women are more willing to address and overcome them to achieve their leadership aspirations. Figure 6 highlights this interaction.

Among people with more than 10 years' experience, there was no significant interaction between gender and the negatives of leadership (Gender $x$ Negatives $\beta>10$ yrs experience $=-.09, p=$ n.s.), and no support for Hypothesis 8. As experience increases, the negatives of leadership that distinguish between men's and women's aspirations disappear. This suggests that for men, the negatives of leadership may begin to weigh on their aspirations as their experience increases, while for women, those same negatives have less influence on their aspirations as they gain experience.

\section{Tables $6 \& 7$ here}

Figure 6 here

\section{Discussion}

\subsection{Theoretical implications}

Findings suggest general support for several hypotheses in our model. Compared with men, women's aspirations to leadership depend on how competent they think they are, how 
negatively they perceive the tradeoffs of leadership to be, and how much experience they have. Our results support findings of many past studies that suggest that gender stereotypes, different career socialization, and sex discrimination contribute to the lack of women in organizational leadership (Athitakis, 2013; Caprino, 2013; Hale, 2009). Further, by examining how these three barriers affect women and men differently, we found that women perceive their competencies, the negatives of leadership, and their experience differently, and this may help explain why there are fewer women than men in leadership positions in American higher education.

It is not surprising that our results indicated that the less competent men and women think they are to be leaders, the less likely they want to be leaders. Perceived self-competence matters: and that makes sense. People who believe they have the competencies and capabilities to do a job are more likely to aspire to that job than people who think they do not have those qualifications. We found no differences between men and women on this general point.

It was also not surprising to discover that the more women associate leadership with negative aspects, the less likely they are to aspire to leadership. The surprising outcome was that this was not the case for men. Many women see that despite potential rewards, leadership may put a high demand on family life, lead to loss of personal and work flexibility, and provide insufficient rewards (Coffman \& Neuenfeldt, 2014). At the same time, men aspire to leadership whether negative aspects of it are high or low. In other words, the negatives matter to too many women and affect their aspirations to leadership, but negatives do not seem to matter to men.

Most remarkable and curious was our finding that the stage in women's careers and their perceived competency affect women's aspirations to leadership differently than they affect men's. We had thought that since men are often very confident about their abilities, and often apply for positions that they are only partially competent to hold, and since women frequently 
are under-confident about their abilities (Ehrlinger \& Dunning, 2003), this lack of confidence is what would drive women's lesser aspirations to leadership (Artabane et al., 2017). However, the results suggest otherwise. What affects women's aspirations to leadership is how much experience they have: competent women with less work experience are more likely to aspire to leadership, compared with men. But competent women with more work experience are less likely to aspire to leadership, compared with men.

When more experienced women perceive themselves to be, and know they are, competent leaders, they are less likely to position themselves to attain leadership positions, compared with men. We observed that women with less work experience who see high negatives to leadership are more likely to aspire to leadership, compared with men. But there was no difference in leadership aspirations among women with more experience who saw high negatives of leadership, compared with similar men. This is interesting as it extends Fritz and van Knippenger's (2014) finding that organizational climate influences employees' leadership aspirations. Here we show that negatives and experience are important conditions within the organizational climate that influence leadership aspirations.

Gender stereotypes, different career socialization and sex discrimination help explain why this counterintuitive result might occur. First, younger women with some experience may not be discouraged yet by leadership's possible negatives and how their competencies may be seen by others. But among senior women with more work experience, it is precisely their longer tenure and their more extensive experience that dampens their aspirations to leadership. One might assume that the more experience a woman has, the more confident and driven she would be to assume the next level of managerial challenge. A McKinsey survey (Lubin, 2017) found that more female middle managers aspired to top leadership roles than female entry-level 
professionals, suggesting that companies that increase the number of middle management women, and retain them, would have more women candidates in the pipeline to assume top management roles.

But our findings suggest a more complex situation, and that the pipeline theory does not work well. Less experienced, entry-level women may be less likely to aspire to leadership when they first begin working. But as they gain experience, and are promoted to positions of greater responsibility, they become more interested in the top roles. Perhaps they obtain and successfully navigate middle management positions, and they become more confident about promotion. But after gaining middle and moderately upper-management experience, something interesting happens. Women who aspire to top levels of leadership encounter significantly more open and subtle resistance than they might expect, as noted by women who once tried for the CEO positions in their companies, but never made it (Chira, 2017). For example, women who achieve top level promotions are more likely than men to be put into high risk leadership positions, and often lack the support or authority to accomplish their strategic goals (Glass \& Cook, 2016). Put simply, many senior women conclude that the barriers are more deeply rooted in discrimination and persistently different socialization patterns than they had formerly believed when they were younger and less experienced. An unfortunate, yet logical, outcome of this would be a greater number of less experienced women leaders, and a smaller number of more experienced women leaders, in organizations.

Indeed, sex discrimination contributes to the negatives that affect women's aspirations to leadership. A female senior executive noted that she "always had to do better than anybody else to be considered equal." But when women do well, and act assertively to assure that it is noticed, men often react badly. Women who negotiate for promotions are $30 \%$ more likely than men to 
be labeled intimidating, bossy, or aggressive (Chira, 2017). Even when women are well established in the upper management pipeline, they are often overlooked. One woman noted in her organization that the men received promotions in two years, while women had to wait three years, with the only explanation being "we're not sure she is ready for the job" (Chira, 2017).

Sex discrimination also manifests itself in the wage gap, and likely deters women from pursuing leadership positions. Recall that women working full time in 2016 made 81 cents for each dollar made by men (U.S. Census Bureau, 2017). The gap is larger among college graduates, and "far larger in business, finance and legal careers than in science and technology jobs" (Gold in, 2017). So, the more professional the field, the larger the wage gap. In 2017, the median female White House employee earned \$72,650, compared to the median male salary of $\$ 115,000$. And in 2011, MSNBC's "Morning Joe" co-host Mika Brzezinski revealed that Joe Scarborough, the show's namesake, made 14 times her salary. Notwithstanding the level of the position, and even for women with high-profile leadership positions, the gap seems to increase with age and when women marry and start to have children (Wootson Jr., 2017).

Professional socialization differences between men and women add to the negatives that deter experienced women's aspirations to leadership. Women say they are often outmaneuvered by male colleagues as they try to move up the organizational ladder. One woman executive helped a man obtain a C-suite job, yet he openly criticized her at the top management table about her business (Chira, 2017). The experience reminded her that at the C-suite level, everyone competes fiercely for the top job. Yet, women are not taught the rules, or how to advocate for themselves, and they are often unprepared for the battle for top positions (Chira, 2017).

Since women are professionally socialized so differently than men, this has a lasting effect on their aspirations to leadership. Women do not want to be treated differently, but in fact, 
men treat women differently. One problem facing women in the workplace is the reluctance of male executives and the absence of female executives to mentor female colleagues and employees (Sandberg \& Scovell, 2013; Coffman \& Nuenfeldt, 2014). Ashford (2013) found that about two-thirds of men in senior positions pulled back from one-on-one contact with junior female employees for fear of being suspected of having an affair. Note that half of junior women reported concern about one-on-one contact with senior men for the same reason (Ashford, 2013), but that may not be surprising given the sexual discrimination, misconduct, and microaggressions that continue in the workplace. Men who mentor men usually are active sponsors who champion them to promotions and new jobs, while men who mentor women typically give advice (Ibarra et al., 2010) and that advice is often patronizing. Such patronizing feedback is a way for the mentor to retain power and put women at a relative disadvantage, which further contributes to the lack of women in leadership positions (Bear et al., 2017).

Finally, sexual misconduct joins sex discrimination and different professional socialization to contribute significant negatives that keep women from pursuing positions of top leadership. In its most egregious form, sexual predation and assault, such as that practiced by disgraced media producer Harvey Weinstein and other powerful men in media and technology, happens so frequently that it chips away at a woman's patience and sense of self, even among women who are strong and successful (Zarya, 2017). It is not surprising that such predation diminishes women's ambitions and aspirations, and unfortunately it often begins when women are young. Women often start their professional careers with optimism, but gendered realities of sexual harassment and assault from men they encounter in the workplace and socially dampen women's autonomy, reinforce different roles for women and men, and influence the choices women make (Stuber et al., 2011), including how ambitious for top positions they might be. 
Sexual misconduct occurs in microaggressions -- those frequent, small and mean-spirited acts that create hostility at work. For example, assertive women are often called bitchy, shrill, aggressive, or pushy, while assertive men are called strong, decisive, and competent (Chira, 2017). Women are often interrupted when they speak, and subject to "mansplaining" (Solnit, 2012), or explaining something to a woman that she already knows, even when she is an expert in the topic. Women tend to deal with microaggressions such as these by brushing them off, not calling them out, and internalizing them. This becomes tiring, then exhausting, as women gain more experience and wisdom about how their organizations work.

Our results suggest that women with more experience, after enduring decades of sex discrimination, exclusionary socialization and covert microaggression, may be tired of fighting against all of this behavior at work, and opt out of the running for higher leadership positions. Successful women note that while the men fight and succeed in negotiating powerful deals for themselves -- and are commended for being fierce and tactical -- the women must balance coming across as assertive but not too aggressive, just to get their fair share (Wootson Jr., 2017). So women soldier on, often to exhaustion such that many of them, especially the more experienced, may decide it is not worth it to advance into top leadership given such a hostile organizational environment.

Women who do hold senior positions note that it is lonely at the top, since they are often the only woman there (Chira, 2017). Men may be averse to working with more senior women, too. In one case, a male $\mathrm{COO}$ considered it "inappropriate" and would not go to lunch - an important bonding activity in business -- with female employees, including his female controller who was his deputy and a direct report, although he regularly went to lunch with all his male direct reports. In another case, a male candidate for a $\mathrm{COO}$ position phoned the company's 
female CEO after receiving her job offer. He asked that they have lunch before he made a decision because he wanted to "make sure that I can work for a woman." The CEO replied, "I'll make this easy for you. We won't go to lunch, and I rescind my offer" (Anonymous, personal communication, November 13, 2017). Anecdotes such as these abound, forming part of the \#metoo litany of microaggressions and lack of respect (Vial et al., 2016) endured by professional women world wide.

In summary, this research found relationships between aspirations to leadership, respondents' experience and the positives and negatives associated with leadership. In doing so, we argue that many of the negatives, including benevolent and hostile sexism, microaggressions, gender role stereotypes, organizational climate, and career socialization contribute to differences in aspirations, and and that, interestingly, experience moderates these negatives differently for women than men.

\subsection{Practical implications}

We found that many women deem themselves as competent, and have extensive professional experience. Yet, women who perceive that leadership has significant negative aspects, and women with more work experience are less likely to aspire to top leadership positions. This is an unfortunate loss of talent, and it suggests that organizations might take concrete steps to reduce the perception of those negatives, and to encourage competent women with significant work experience to seek higher positions. Traditional solutions to this underrepresentation of women in leadership include getting more women into the organizational leadership pipeline (Stewart, 2016), encouraging women to lean in and promote themselves (Sandberg \& Scovell, 2013), and diversity training for all organizational members (Kolowich, 2015). But decades of these approaches has not moved the needle significantly toward increasing 
the number and level of women in leadership positions (Wallace, 2017). As noted throughout this paper, women, particularly experienced women, are still underrepresented in higher leadership in business, politics, and academia.

Since discrimination, socialization, and misconduct in the workplace seem to contribute to women's reluctance to aspire to leadership, practical solutions must begin there. There are specific actions leaders of organizations could take to begin to reverse the course and truly increase the representation of women in leadership, and we suggest some below.

First, provide monetary and other real, non-monetary incentives to women that make the prospect of leadership more attractive, and less negative. For example, pay women the same as men for the same positions and responsibilities. Make salaries transparent so that employees are knowledgeable of what their male and female colleagues earn, and this will begin to close the wage gap. Offer family leave to both women and men, knowing that is especially important to women because they are frequently most responsible for juggling family responsibilities even when they hold positions of significant responsibility. Provide opportunities for flexible working hours and locations so women and men have options to manage dual careers, families, and other priorities. Tangible incentives such as these will begin to convince women that the positives of leadership in her organization outweigh the negatives.

Proactively promote and sponsor women: do not expect them to always self-promote. Recall that men who "mentor" other men tend to proactively sponsor them, whereas men who mentor women often just give them advice (Ibarra et al., 2010) - and many men resist mentoring women at all. Instead, build formal mentoring programs that are created and overseen by the organization, removing the social awkwardness of expecting men and women to seek each other out. Formal mentorship programs give mentors and mentees a common set of goals to 
accomplish, and they make those goals clear to the rest of the company (Dobbin \& Kalev, 2016). Institutionalizing a formal mentoring program discourages gossip and suggestive comments since it is built into the company's culture. At Google, a senior engineer sends out regular "nudge" notes - emails to employees explaining promotion opportunities - urging women to nominate themselves. Results have been positive: when the notes are sent, more women nominate themselves (Wall Street Journal, 2012). More women nominating themselves suggests they see opportunities and positive aspects to leading, which may overcome what they perceive as negatives. Then, once more women are in top leadership, there will be enough women leaders who can join men to mentor up-and-coming employees for future leadership positions.

Require that women are seated at all the tables. One practice is to require that corporate recruiters bring diverse slates of candidates. If organizations do not ask for this, recruiters will tend to suggest people that they have seen before and who look very similar to the current leadership - which as noted, is usually male. This parallels a National Football League practice that stipulates that the NFL must interview minority candidates for every senior job opening (Lipman, 2018, 140). Another practice is for men to stipulate that professional panels they are asked to participate in, or boards they are asked to serve on, not be all-male. Men can ask recruiters to find female experts to join them in these and other professional groups, and suggest some themselves. Such a formal inclusion practice suggests to women that their experience and competence is respected, and helps reduce the negatives while increasing the positive attributes of organizational leadership.

Use "blind auditions" to help fill leadership positions with more diverse candidates. Several firms have experimented with filling technical jobs through "blind auditions" in which applicants complete a test that is evaluated by a hiring manager who knows nothing about the 
applicant: not gender, age, schooling, or name (Miller, 2016). Comedian Samantha Bee, producer and star of Full Frontal, applied "blind auditions" to their recruitment of writers. To level the playing field, the show's producers created a detailed instruction packet for applicants, so that every application that landed on the head producer's desk looked exactly the same: there was no way to tell men from women, or whites from non-white. As a result, Full Frontal's writing staff was split evenly between men and women, and 25\% were minorities (Morris, 2016). Women who see more female role models in their organizations begin to understand that these leaders successfully tackled the trade-offs of leadership, and they may be encouraged to do the same.

Speak out against gender-based misconduct in the workplace. Sexual misconduct ranges from demeaning "bro talk" among men about women, to casual derision in the form of a flip remark to women that they are not respected or taken seriously, to outright sexual assault against women (Lipman, 2018), and it occurs in most if not all industries. Men know it happens: they see it, they hear it, they watch it, and yet they often do little to stop it. Why not? Many say that it is uncomfortable calling out other men, and could be embarrassing, emasculating, and bad for their careers. However, individuals who witness gender-based misconduct, and especially men, must speak up in their organizations to stop the rampant lack of respect toward women (Polk, 2016). Sam Polk, co-founder and CEO of Everytable, writes "men of status in our wider culture managers, coaches, politicians, and celebrities" must speak out and insist that women are spoken to and spoken about with respect (Polk, 2016). When a person someone makes an offensive or belittling comment about women, an observer's gently-put question such as "What did you mean by that?" might spark reflection and jolt the person into changing their behavior (Lipman, 2018). Women - and men - know that sexual misconduct is common in most, if not all, industries. 
Victim's stories confirm that this aggression has at least discouraged women from denouncing it, and at worst derailed women's careers. Dealing with sexual misconduct is a significant negative challenge to women seeking advancement, and it is imperative that it vanish from organizational life to ensure integrity for all.

\section{Limitations}

This study has limitations that could be addressed by future research. The first is our sample, which, while it is a diverse and cross-disciplinary population from many higher education organizations, it is limited to people who live in the U.S. midwest region. An original objective of this research was to compare aspirations of women, and especially minority women to leadership, but the numbers of minority individuals in the sample population was too small to determine any significant effects. It is also limited to universities, which is just one industry, while at the same time providing a population with more balanced numbers of men and women than might be found in other industries such as heavy manufacturing or finance. Nevertheless, future research is an avenue to test these findings by surveying populations in other industries, and in other regions of the U.S. and the world, to reflect other occupational, cultural and sociopolitical environments where aspirations to leadership, and perceptions of competency and negatives of leadership may differ. The limitations of this study provide a canvas for blocking strategies for future studies that might extend our findings to other workplace environments.

A second limitation reflects a potential socio-desirability bias. Individuals who took the survey may have responded more positively to the questions, reflecting a higher level of aspirations or fewer negatives associated with leadership, due to the desire to limit potential negative outcomes of the study. We took steps to mitigate social desirability by articulating the purpose of the research, ensuring anonymity, and gathering a large sample from the populations 
to reflect a full range of responses. We attempted to link those personal responses with outcomes in order to determine if the social response was indicative of actual outcomes. A thread of future research might explicitly link the survey data with external qualifiers of leadership, to test if these individual perceptions resulted or not in leadership growth. This would extend the discussion of perceived barriers and their effect on limiting aspirations to leadership, to test whether or not removing or mitigating them results in moving the needle toward stronger leadership growth.

A third limitation is regarding confounding variables. Statistical tests suggest no internal endogeneity within the model, yet it is possible that other factors that were not included in our model might also influence leadership aspirations. Our model is an attempt to suggest new theoretical connections between women and leadership. The model, which connected unrelated theories of gender, the negatives of leadership, competence, and experience, brings new insight to the field by suggesting these relationships. And while these are important and interesting, it is equally important to investigate other variables. Concerns about the maternal wall and the role of benevolent sexism might be further addressed in light of our model to develop these relationships further. Mentorship, role models, and organizational climate could be powerful variables that could help further explain these complex connections. Future research might capture effects of those and other variables and ask how they might explain differences in aspirations to leadership.

\section{Conclusion}

In conclusion, we offer new insights that might help to explain what motivates women to aspire, or not aspire, to leadership. We found that men and women have different attitudes about their respective competencies, experience, and aspirations to leadership, and we suggested some explanations to help us understand why, in 2018, women are still underrepresented in 
organizational leadership. Our finding that highly competent women with more work experience aspire to leadership positions significantly less than men do, and less than women with less experience do, suggests that these women know something important about leadership that we may not yet fully understand. These women often find leadership negative, perhaps unbearable, which makes them less likely to want the jobs. This reduced aspiration may have the unfortunate outcome of fewer experienced people - namely women -- in positions of leadership, which modern organizations desperately need. Fortunately, there are ways for organizations to mitigate this and encourage more women at all levels of experience to aspire and compete for leadership positions. Organizations can adopt policies that provide women monetary and non-monetary incentives, mentorship and sponsorship from within, seats at decision-making tables at all levels, and the elimination of sexual misconduct in the workplace. These policies might convince women that leadership, while still a formidable burden, is not the unbearable load that experienced women candidates have found it to be. 


\section{References}

Antonakis, J., Bendahan, S., Jacquart, P., \& Lalive, R. (2010). On making causal claims: A review and recommendations. The Leadership Quarterly, 21, 1086-1120.

Artabane, M., Coffman, J., \& Darnell, D. (2017). Charting the course: Getting women to the top. Bain Brief. Boston: Bain \& Company. Retrieved from http://www.bain.com/publications/articles/charting-the-course-women-on-the-top.aspx.

Ashford, K. (2013, May 3). Are men afraid to mentor women? Forbes. Retrieved from https://www.forbes.com/sites/learnvest/2013/05/03/are-men-afraid-to-mentorwomen/\#6f1275f52481.

Ashford, K. (2017). Why men don't mentor younger women - and how we can change that. Retrieved from https://www.themuse.com/ad vice/why-men-dont-mentor-youngerwomenand-how-we-can-change-that.

Athitakis, M. (2013). Are women and minority leaders set up to fail? Retrieved from http://associationsnow .com/2013/07/are-women-and-minority-leaders-set-up-to-fail.

Barclay, T. A., Perelli, S. J., Somers, T. M., \& Goodaker, C. (2017). Women's leadership in Michigan top public companies 2007-2017: A call for championship [PDF document]. Retrieved from https://inforummichigan.org/wpcontent/uploads/2017/11/Inforum_LeadershipIndex17_Web.pdf. 
Bear, J. B., Cushenbery, L., London, M., \& Sherman, G. D. (2017). Performance feedback, power retention, and the gender gap in leadership. Leadership Quarterly, 28(6), 721-740. doi: 10.1016/j.leaqua.2017.02.003.

Budig, M. J. (2014). The fatherhood bonus and the motherhood penalty: Parenthood and the gender gap in pay. Washington, DC: Third Way.

Caprino, K. (2013, February 12). The top 6 reasons women are not leading in corporate America as we need them to. Forbes. Retrieved from http://www.forbes.com/sites/kathycaprino/2013/02/12/the-top-6-reasons-women-are-notleading-in-corporate-america-as-we-need-them-to/.

Chira, S. (2017, July 21). Why women aren't CEOS, according to women who almost were. New York Times. Retrieved from https://www.nytimes.com/2017/07/21/sundayreview/women-ceos-glass-ceiling.html.

Coffman, J., \& Neuenfeldt, B. (2014). Everyday Moments of Truth. Frontline Managers are Key to Women's Career Aspirations. Bain \& Company (Hg.). Retrieved from http://www.bain.com/publications/articles/everyday-moments-of-truth.aspx 
Crites, S. N., Dickson, K. E., \& Lorenz, A. (2015). Nurturing gender stereotypes in the face of experience: A study of leader gender, leadership style, and satisfaction. Journal of Organizational Culture, Communications and Conflict, 19(1), 1-23.

Deutsch, F. M., \& Yao, B. (2014). Gender differences in faculty attrition in the USA. Community, Work \& Family, 17(4), 392-408. doi: 10.1080/13668803.2014.885880.

Dobbin, F., \& Kalev, A. (2016). Why diversity programs fail. Harvard Business Review, JulyAugust. Retrieved from https://hbr.org/2016/07/why-diversity-programs-fail.

Donnelly, G. (2017, June 7). Only 3\% of fortune 500 companies share full diversity data. Fortune. Retrieved from http://fortune.com/2017/06/07/fortune-500-diversity/.

Eagly, A. H., \& Carli, L. L. (2007). Women and the labyrinth of leadership. Harvard Business Review, 85(9).

Eagly, A. H., \& Karau, S. J. (2002). Role congruity theory of prejudice toward female leaders. Psychological review, 109(3), 573.

Eagly, A. H., Makhijani, M. G., \& Klonsky, B. G. (1992). Gender and the evaluation of leaders: A meta-analysis. Psychological bulletin, 111(1), 3. 
Eccles, Jacquelynne S. 1987. Gender Roles and Women's Achievement-Related Decisions. Psychology of Women Quarterly, Vol 11, Issue 2, pp. 135 - 172.

Ehrlinger, J., \& Dunning, D. (2003). How chronic self-views influence (and potentially mislead) estimates of performance. Journal of Personality and Social Psychology, 84, 5-17.

England, P., Bearak, J., Budig, M. J., \& Hodges, M. J. (2016). Do highly paid, highly skilled women experience the largest motherhood penalty?. American Sociological Review, 81(6), 1161-1189.

Fitzsimmons, T. W., Callan, V. J., \& Paulsen, N. (2014). Gender disparity in the C-suite: Do male and female CEOs differ in how they reached the top? The Leadership Quarterly 25(2):245-266.

Fritz, C., \& van Knippenberg, D. L. (2017). Gender and leadership aspiration: Interpersonal and collective elements of cooperative climate differentially influence women and men. Journal of Applied Social Psychology, 47(11):591-604. doi: 10.1111/jasp.12462.

Glass, C., \& Cook, A. (2016). Leading at the top: Understanding women's challenges above the glass ceiling. Leadership Quarterly, 27(1), 51-63. doi: 10.1016/j.leaqua.2015.09.003.

Goldin, C. (2017, November 10). How to win the battle of the sexes over pay. The New York Times. Retrieved from https://www.nytimes.com/2017/11/10/business/how-to-win-thebattle-of-the-sexes-over-pay-.html?_r=1. 
G.V., X. (2017, October 26). Can we talk about the gender pay gap? The Washington Post. Retrieved from https://www.washingtonpost.com/graphics/2017/business/women-paygap/?utm_term=.7660ce557af7.

GVSU Climate Assessment Project. (2011). Allendale, MI: Grand Valley State University. Retrieved from http://www.gvsu.edu/mygvsu/.

Hair, J. F., Black, W. C., Babin, B. J., Anderson, R. E., \& Tatham, R. L. (1998). Multivariate Data Analysis Upper Saddle River, NJ: Prentice hall.

Hale, M. A. (2009). Minority women in administrative professional positions in higher education. Retrieved from Iowa State University Digital Repository: Graduate Theses and Dissertations. 10319.

Hegewisch, A., \& DuMonthier, A. (2016). The Gender Wage Gap: 2015: Annual Earnings Differences by Gender, Race, and Ethnicity. Fact Sheet, IWPR C, 446 [PDF document]. Retrieved from https://iwpr.org/publications/the-gender-wage-gap-2015-annual-earning sdifferences-by-gender-race-and-ethnicity/

Hegewisch, A., \& Hartmann, H. (2014). Occupational segregation and the gender wage gap: A job half done [PDF document]. Retrieved from 
https://www.dol.gov/wb/resources/occupational_segregation_and_wage_gap.pdf.

Heilman, M. E. (2012). Gender stereotypes and workplace bias. Research in Organizational Behavior, 32, 113-135.

Hoobler, J. M., Lemmon, G., \& Wayne, S. J. (2014). Women's managerial aspirations: An organizational development perspective. Journal of Management, 40(3), 703-730.

Hunt, V., Layton, D., \& Prince, S. (2015). Why diversity matters. Retrieved from https://www.mckinsey.com/business-functions/organization/our-insights/why-diversitymatters.

Ibarra, H., Carter, N. M., \& Silva, C. (2010, September). Why men still get more promotions than women. Harvard Business Review. Retrieved from https://hbr.org/2010/09/whymen-still-get-more-promotions-than-women.

Johnson, H. L. (2016). Pipelines, pathways, and institutional leadership: An update on the status of women in higher education [PDF document]. Retrieved from http://www.acenet.edu/news-room/Documents/Higher-Ed-Spotlight-Pipelines-Pathwaysand-Institutional-Leadership-Status-of-Women.pdf.

Jones, S. J., \& Palmer, E. M. (2011). Glass ceilings and catlights: Career barriers for professional women in academia. Advancing Women in Leadership, 31, 189-198. 
Kitroeff, N \& Silver-Greenburg, J. (2018, June 15). Pregnancy Discrimination Is Rampant Inside America's Biggest Companies. New York Times. Retrieved from https://www.nytimes.com/interactive/2018/06/15/business/pregnancydiscrimination.html.

Koenig, A. M., Eagly, A. H., Mitchell, A. A., \& Ristikari, T. (2011). Are leader stereotypes masculine? A meta-analysis of three research paradigms. Psychological Bulletin, 137(4), 616.

Kolowich, S. (2015). Diversity training is in demand. Does it work? The Chronicle of Higher Education, 62(13).

Konrad, A. M., \& Pfeffer, J. (1991). Understanding the hiring of women and minorities in educational institutions. Sociology of Education, 64(3), 141-157.

Lafrance, A. (2016, March 30). Why Do So Many Digital Assistants Have Feminine Names? Hey Cortana. Hey Siri. Hey girl. The Atlantic. Retrieved from https://www.theatlantic.com/technology/archive/2016/03/why-do-so-many-digitalassistants-have-feminine-names/475884/. 
Lapin, L., \& Sullivan, K. J. (2014). Women less represented in faculty, staff leadership ranks. Retrieved from https://news.stanford.edu/news/2014/march/facsen-faculty-report030614.html.

Laughlin, L. (2013). Who's Minding the Kids? Child Care Arrangements: Spring 2011 [PDF document]. Retrieved from https://www.census.gov/prod/2013pubs/p70-135.pdf.

Lennon, T. (2013). Benchmarking women's leadership in the United States [PDF document]. Retrieved from https://womenscollege.du.edu/media/ documents/BenchmarkingWomensLeadershipintheUS.pdf.

Leon, R. A., \& Jackson, J. F. L. (2009). Examining academic leadership position attainment in higher education: Evidence from NSOPF 99. Annals of the Next Generation, 2(1), 46-63.

Leonard, N. (2013, February 16). Too few women and minorities in leadership roles, report says. The McGill Daily. Retrieved from https://www.mcgilldaily.com/2013/02/too-fewwomen-and-minorities-in-leadership-roles-report-say s/.

Lipman, J. (2018). That's what she said: What men need to know (and women need to tell them) about working together. New York: Harper Collins. 
Lubin, J. S. (2017, October 10). Getting women out of the middle-management trap. The Wall Street Journal. Retrieved from https://www.wsj.com/articles/getting-women-out-of-themiddle-management-trap-1507608361.

Milkman, K. L., Akinola, M., \& Chugh, D. (2015). What happens before? A field experiment exploring how pay and representation differentially shape bias on the pathway into organizations. Journal of Applied Psychology, 100(6), 1678-1712. doi: 10.1037/ap10000022.

Miller, C. C. (2016, February 25). Is blind hiring the best hiring? The New York Times. Retrieved from https://www.nytimes.com/2016/02/28/magazine/is-blind-hiring-the-besthiring.html?_r=0.

Moor, A., Cohen, A., \& Beeri, O. (2015). In quest of excellence, not power: Women's paths to positions of influence and leadership. Advancing Women in Leadership, 35, 1-11.

Morris, A. (2016). How Samantha Bee crashed the late-night boys' club. Retrieved from https://www.rollingstone.com/tv/features/how-samantha/bee-crashed-the-late-night-boysclub-20160630\#ixzz4DXSiiQDS.

Moya, M., Glick, P., Expósito, F., De Lemus, S., \& Hart, J. (2007). It's for your own good: Benevolent sexism and women's reactions to protectively justified restrictions. Personality and Social Psychology Bulletin, 33(10), 1421-1434. 
Myatt, M. (2013, November 18). Top 10 reasons why diversity is good for the boardroom. Forbes. Retrieved from http://www.forbes.com/sites/mikemyatt/2013/11/18/top-10reasons-diversity-is-good-for-the-board room/.

Nass, C., \& Yen, C. (2010). The man who lied to his laptop: What we can learn about ourselves from our machines. New York: Current.

O’Connor, C. (2013, November 9). Women lag in leadership roles, CEO earnings, new national report shows. The Denver Post. Retrieved from https://www.denverpost.com/2013/11/09/women-lag-in-leadership-roles-ceo-earningsnew-national-report-shows/.

Oguntoyinbo, L. (2014). To Go Co-Ed Or Not? Diverse Issues in Higher Education, 31(8), 14.

Parsons, J. E., Ruble, D.N., Hodges, K. L., \& Small, A.W. (1976). Cognitive-Developmental Factors in Emerging Sex Differences in Achievement-Related Expectancies. Journal of Social Issues, 32:3 (47-). https://doi-org.ezproxy.gvsu.edu/10.1111/j.15404560.1976.tb02596.x

Perryman, A. A., Fernando, G.D., \& Tripathy, A. (2016). Do gender differences persist? An examination of gender diversity on firm performance, risk, and executive compensation. Journal of Business Research, 69(2), 579-586. doi.org/10.1016/j.jbusres.2015.05.013. 
Peus, C., Braun, S., \& Knipfer, K. (2015). On becoming a leader in Asia and America: Empirical evidence from women managers. Leadership Quarterly, 26(1), 55-67. doi: 10.1016/j.leauqua.2014.08.004.

Polk, S. (2016, July 7). How Wall Street Bro talk keeps women down. The New York Times. Retrieved from https://www.nytimes.com/2016/07/10/opinion/sunday/how-wall-streetbro-talk-keeps-women-down.html.

Ramaswami, A., Huang, J., \& Dreher, G.F. (2014). Mentoring across cultures: The role of gender and marital status in Taiwan and the U.S. Journal of Business Research, 67(12), 2542-2549. doi.org/10.1016/j.jbusres.2014.03.013.

Ramos, M. R., Barreto, M., Ellemers, N., Moya, M., Ferreira, L., \& Calanchini, J. (2016). Exposure to sexism can decrease implicit gender stereotype bias. European Journal of Social Psychology, 46(4), 455-466.

Sandberg, S., \& Scovell, N. (2013). Lean in: Women, work, and the will to lead. New York: Alfred A. Knopf.

Solnit, R. (2012, November 1). A Cultural History of Mansplaining. The Atlantic. Retrieved from https://www.theatlantic.com/sexes/archive/2012/11/a-cultural-history-ofmansplaining/264380/. 
Spencer, S. J., Steele, C. M., \& Quinn, D. M. (1999). Stereotype threat and women's math performance. Journal of Experimental Social Psychology, 35, 4-28.

Steele, C. M. (1997). A threat in the air: How stereotypes shape intellectual identity and performance. American Psychologist, 52, 613-629.

Stewart, C. (2016). How diverse is your pipeline? Developing the talent pipeline for women and black and ethnic minority employees. Industrial and Commercial Training, 48(2), 61-66.

Stuber, J. M., Klugman, J., \& Daniel, C. (2011). Gender, social class, and exclusion: collegiate peer cultures and social reproduction. Sociological Perspective, 54(3), 431-451. doi: 10.1525/sop.2011.54.3.431.

U.S. Bureau of Labor Statistics. (2017). Highlights of women's earnings in 2016. Retrieved from https://www.bls.gov/opub/reports/womens-earnings/2016/home.htm.

U.S. Census Bureau. (2017). Historical income tables: People. Retrieved from https://www.census.gov/data/tables/time-series/demo/income-poverty/historical-incomepeople.html.

U.S. Census Bureau. (2012). Statistical Abstract of the United States. Section 12. Labor Force, Employment, and Earnings. Retrieved from 
https://www.census.gov/library/publications/2011/compendia/statab/131ed/labor-forceemployment-earnings.html

U.S. Department of Labor. (2017). Women's median earnings 82 percent of men's in 2016. Retrieved from www.bls.gov/opub/ted/2017/womens-median-earnings-82-percent-ofmens-in-2016.htm.

U.S. Equal Employment Opportunity Commission. (2017a). EEOC charge receipts by state (including U.S.territories) and basis for 2016. Retrieved from https://www1.eeoc.gov/eeoc/statistics/enforcement/state_16.cfm.

U.S. Equal Employment Opportunity Commission. (2017b). Sex-based charges (Charges filed with EEOC) FY1997 - FY2017. Retrieved from https://www.eeoc.gov/eeoc/statistics/enforcement/sex.cfm.

Vial, A. C., Napier, J. L., \& Brescoll, V. L. (2016). A bed of thorns: Female leaders and the selfreinforcing cycle of illegitimacy. Leadership Quarterly, 27(3), 400-414. doi: 10.1016/j.leaqua.2015.12.004.

Wall Street Journal. (2012, May 1). Women in the Google workplace. Retrieved from http://www.wsj.com/video/women-in-the-google-workplace/16A9B911-E7D9-4E1D99E1-979CB1B0F35C.html.

Wallace, W. T. (2017). The journey for women in the transition to senior leadership. People \& Strategy, 40(1), 34-38. 
Williams, J. C., \& Cooper, H. C. (2004). The public policy of motherhood. Journal of Social Issues, 60(4), 849-865.

Wootson Jr., C. R. (2017). A Google engineer wrote that women may be unsuited for tech jobs. Women wrote back. Washington Post, 6.

Zarya, V. (2017). Biggest purge: The sexual harassment tidal wave. Fortune, December 15: 21. 
Figure 1 -- Model of Women's Aspirations to Leadership: Competency and Experience

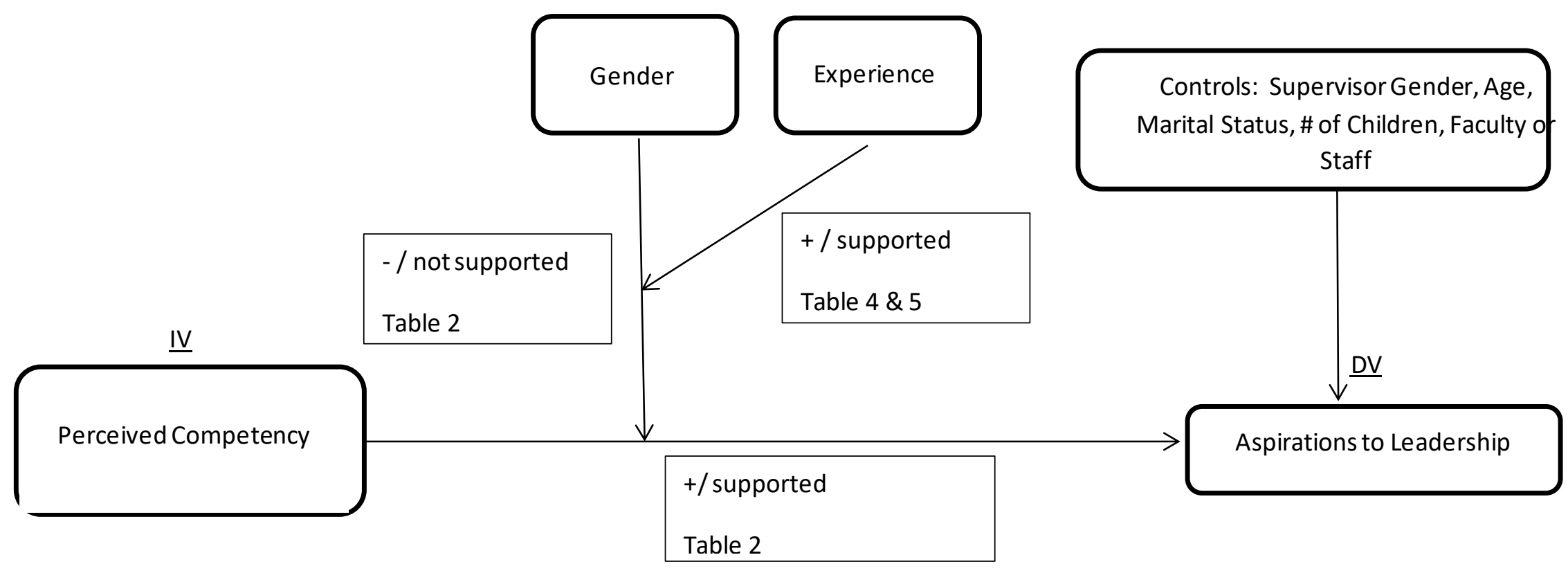


Figure 2 -- Model of Women's Aspirations to Leadership: Negatives of Leadership and Experience

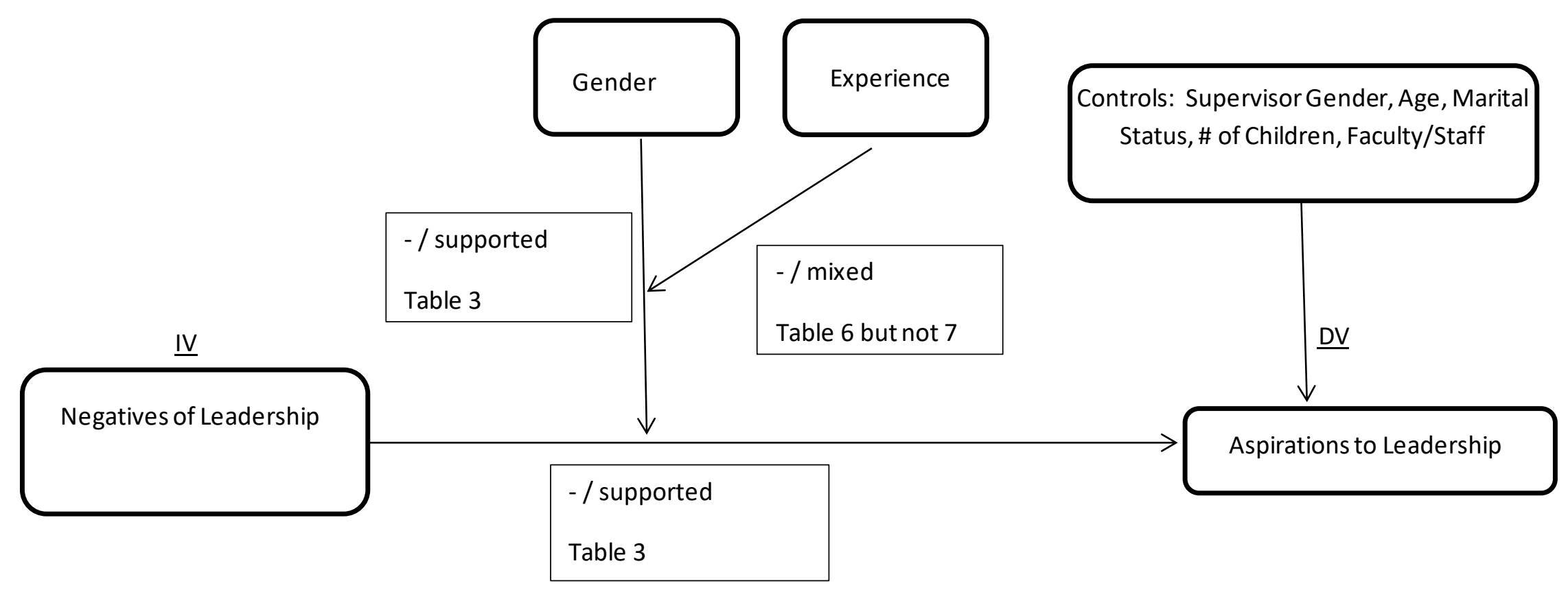


Figure 3: Aspiration to Leadership by Gender and Negatives of Leadership

\section{Aspirations to Leadership}

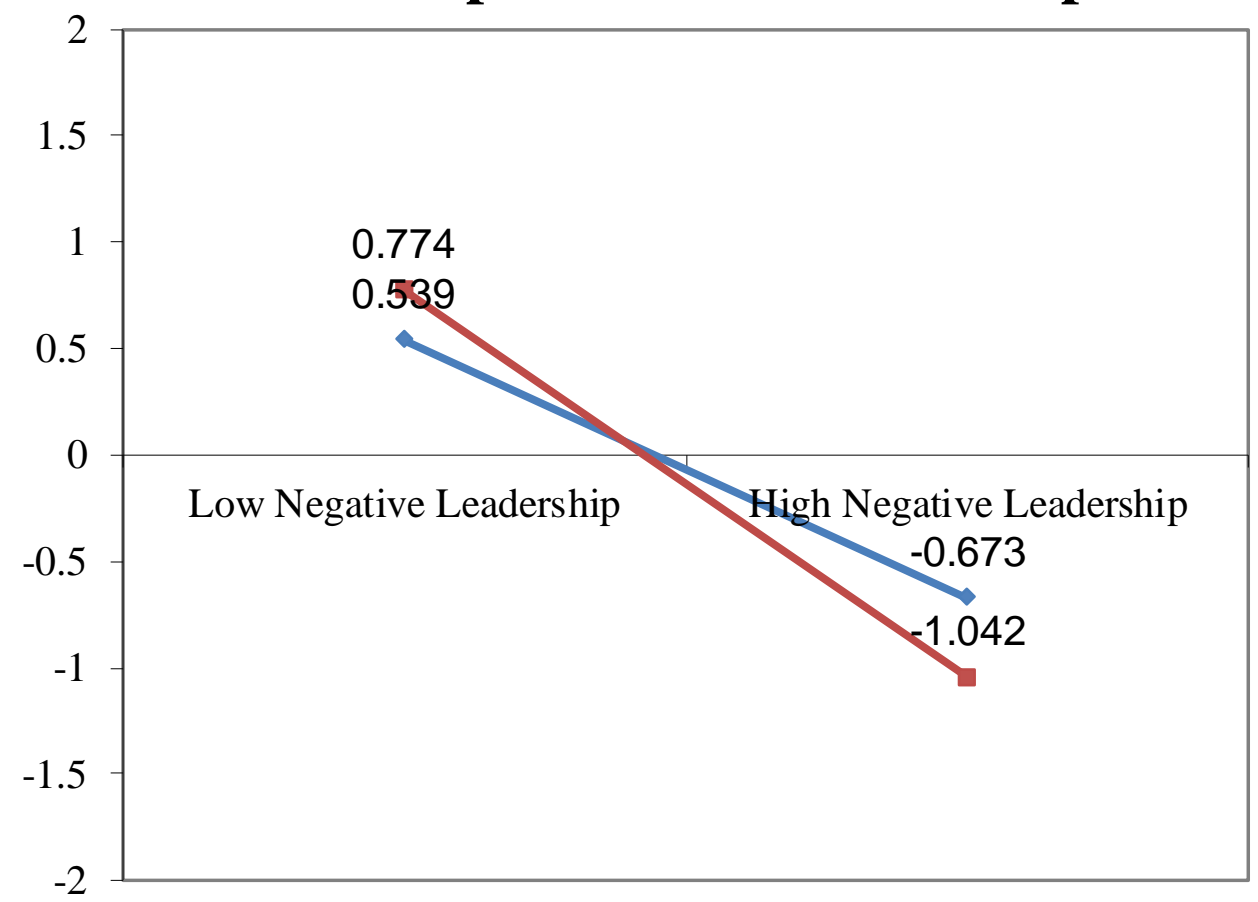

$\leadsto$ Men

- Women 
Figure 4: Perceived Competency by Gender for those with < 10yrs experience

Aspirations to Leadership

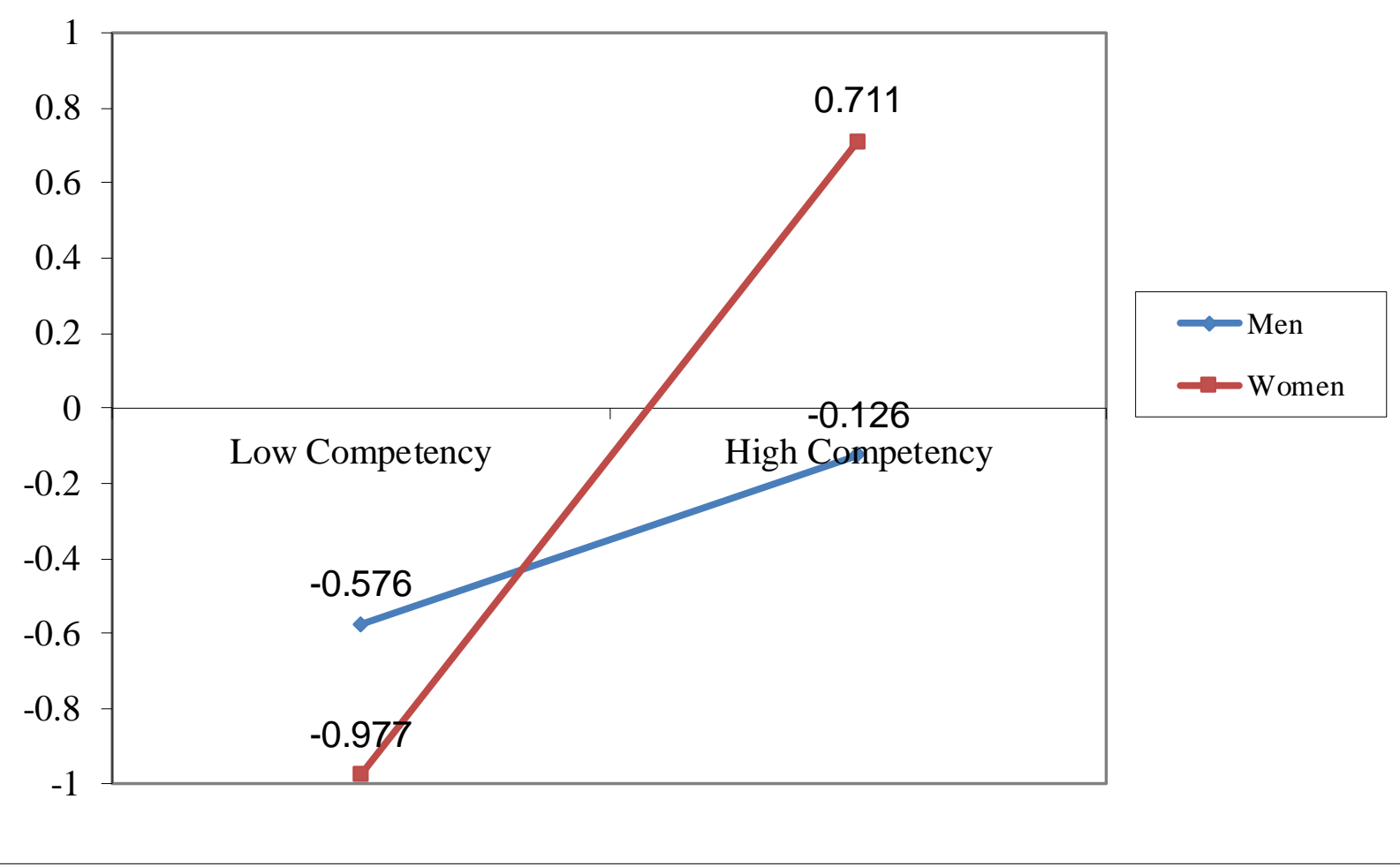


Figure 5: Aspirations to Leadership by Gender for those with >10yrs experience

\section{Aspirations to Leadership}

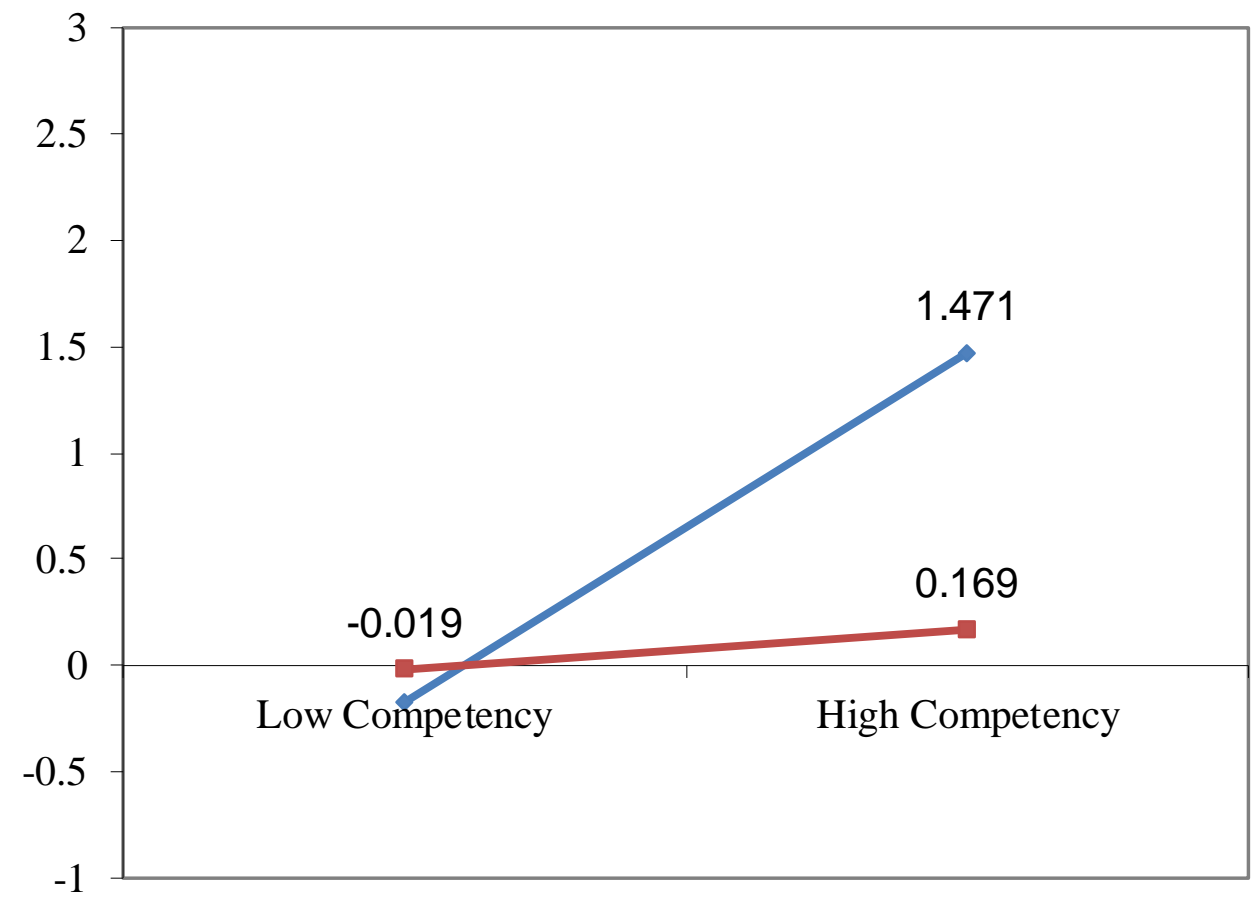


Figure 6: Aspirations to Leadership by Gender for those with <10yrs experience

\section{Aspirations to Leadership}

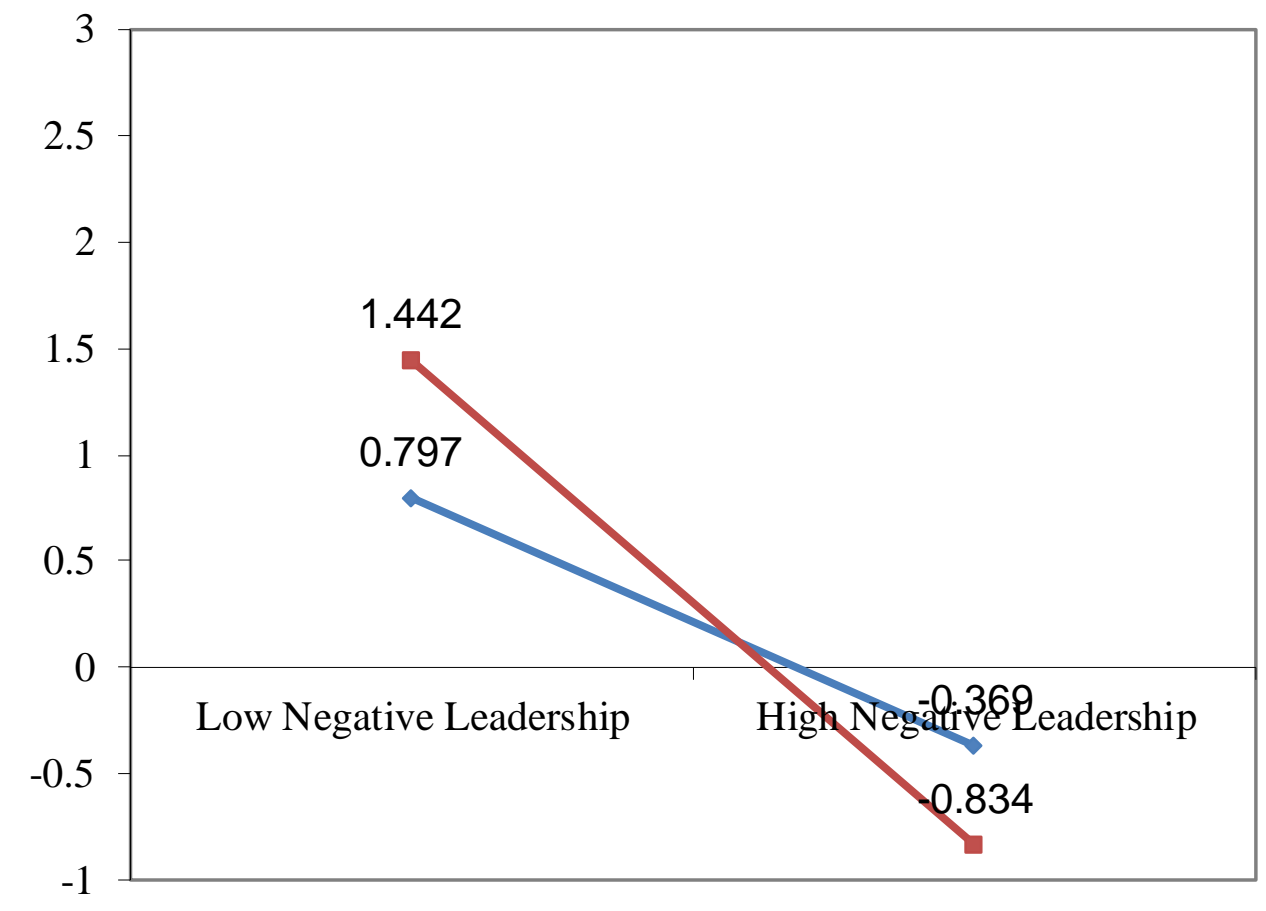


Table 1 - Correlations and Descriptive Statistics

\begin{tabular}{|c|c|c|c|c|c|c|c|c|c|c|c|c|}
\hline & Mean & s.d. & 1 & 2 & 3 & 4 & 5 & 6 & 7 & 8 & 9 & 10 \\
\hline 1. Supervisor Gender & .58 & .49 & 1 & .033 & -.035 & -.020 & $-.096^{*}$ & -.048 & $.182^{* *}$ & .035 & -.020 & .048 \\
\hline 2. Ethnicity & .15 & .36 & & 1 & -.062 & .033 & $.107^{* *}$ & -.053 & $.103^{*}$ & .045 & $-.113^{* *}$ & .015 \\
\hline 3. Age & 46.86 & 12.43 & & & 1 & -.064 & $.381^{* *}$ & $.282^{* *}$ & -.030 & .074 & .051 & $-.268^{* *}$ \\
\hline 4. Marital Status & .26 & .44 & & & & 1 & $-.302^{* *}$ & $-.091^{*}$ & .077 & .006 & $-.130^{* *}$ & -.043 \\
\hline 5. Number of Children & 1.60 & 1.40 & & & & & 1 & $.108^{* *}$ & -.027 & -.016 & .029 & $-.106^{* *}$ \\
\hline 6. Faculty / Staff & .46 & .50 & & & & & & 1 & -.074 & $-.110^{* *}$ & $.187^{* *}$ & $-.266^{* *}$ \\
\hline 7. Employee Gender & .67 & .47 & & & & & & & 1 & .076 & -.051 & .056 \\
\hline 8. Perceived Competency & 7.67 & .29 & & & & & & & & 1 & $-.108^{* *}$ & $.204^{* *}$ \\
\hline 9. Negatives of Leadership & 3.16 & 1.01 & & & & & & & & & 1 & -.062 \\
\hline 10. Aspiration to Leadership & 3.60 & .95 & & & & & & & & & & 1 \\
\hline
\end{tabular}


Table 2: Perceived Competency

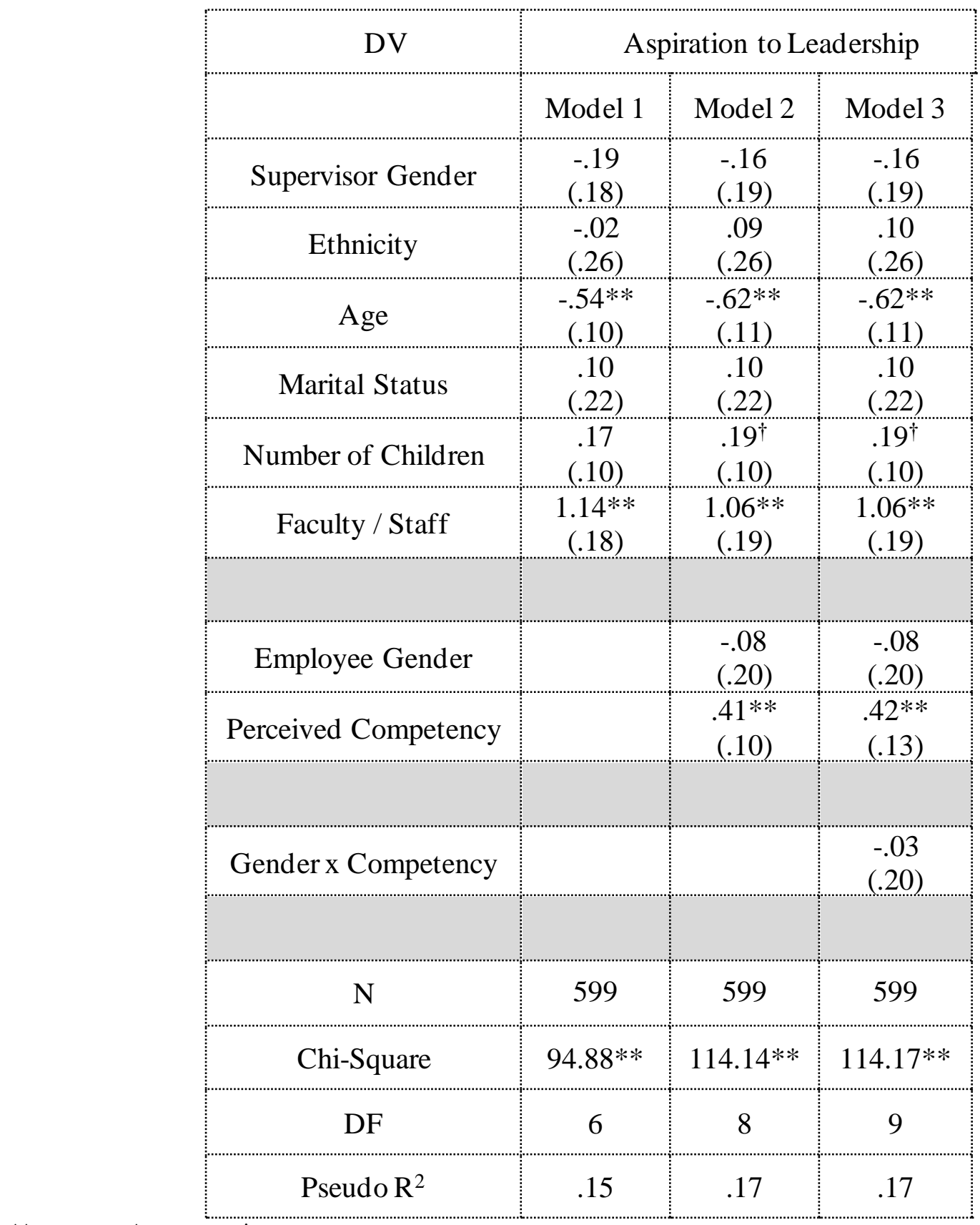

${ }^{* *} \mathrm{P}<0.01,{ }^{*} \mathrm{P}<0.05,{ }^{\dagger} \mathrm{P}<0.08$; Numbers in parenthesis represent standard error 
Table 3: Negatives of Leadership

\begin{tabular}{|c|c|c|c|}
\hline \multirow[t]{2}{*}{ DV } & \multicolumn{3}{|c|}{ Aspiration to Leadership } \\
\hline & Model 1 & Model 2 & Model 3 \\
\hline Supervisor Gender & $\begin{array}{l}-.07 \\
(.12)\end{array}$ & $\begin{array}{l}-.07 \\
(.24)\end{array}$ & $\begin{array}{l}-.07 \\
(.13)\end{array}$ \\
\hline Ethnicity & $\begin{array}{l}-.18 \\
.18)\end{array}$ & $\begin{array}{l}-.06 \\
.19)\end{array}$ & $\begin{array}{l}-.07 \\
(.19)\end{array}$ \\
\hline Age & $\begin{array}{c}-.55^{* * *} \\
(.07)\end{array}$ & $\begin{array}{c}-.60 * * \\
(.07)\end{array}$ & $\begin{array}{c}-.61 * * \\
(.07)\end{array}$ \\
\hline Marital Status & $\begin{array}{c}.01 \\
. .16)\end{array}$ & $\begin{array}{c}.13 \\
(.16)\end{array}$ & $\begin{array}{c}.12 \\
. .16)\end{array}$ \\
\hline Number of Children & $\begin{array}{c}.190^{* *} \\
(.07)\end{array}$ & $\begin{array}{l}.24 * * \\
(.07)\end{array}$ & $\begin{array}{l}.24 * * \\
(.08)\end{array}$ \\
\hline Faculty / Staff & $\begin{array}{c}1.05^{* *} \\
(.23)\end{array}$ & $\begin{array}{l}.78^{* *} \\
(.13)\end{array}$ & $\begin{array}{l}.77^{* *} \\
(.13)\end{array}$ \\
\hline Employee Gender & & $\begin{array}{l}-.10 \\
(.13)\end{array}$ & $\begin{array}{l}-.07 \\
(.14)\end{array}$ \\
\hline Negatives of Leadership & & $\begin{array}{l}-.70^{* *} \\
(.07)\end{array}$ & $\begin{array}{c}-.61^{* *} \\
(.09)\end{array}$ \\
\hline $\begin{array}{l}\text { Gender x Negative of } \\
\text { Leadership }\end{array}$ & & & $\begin{array}{l}-.30^{*} \\
(.16)\end{array}$ \\
\hline $\mathrm{N}$ & 1240 & 1240 & 1240 \\
\hline Chi-Square & $\begin{array}{c}180.63^{*} \\
*\end{array}$ & $288.43 * *$ & $293.805 * *$ \\
\hline $\mathrm{DF}$ & 6 & 8 & 9 \\
\hline Pseudo $\mathrm{R}^{2}$ & .14 & .21 & .213 \\
\hline
\end{tabular}

${ }^{* *} \mathrm{P}<0.01,{ }^{*} \mathrm{P}<0.05,{ }^{\dagger} \mathrm{P}<0.08$; Numbers in parenthesis represent standard error 
Table 4: Perceived Competency $x$ those working less than 10 years

\begin{tabular}{|c|c|c|c|}
\hline \multirow[t]{2}{*}{ DV } & \multicolumn{3}{|c|}{ Aspiration to Leadership } \\
\hline & Model 1 & Model 2 & Model 3 \\
\hline Supervisor Gender & $\begin{array}{l}-.27 \\
(.25)\end{array}$ & $\begin{array}{l}-.28 \\
(.25)\end{array}$ & $\begin{array}{l}-.28 \\
(.26)\end{array}$ \\
\hline Ethnicity & .27 & .31 & .25 \\
\hline Age & $\begin{array}{c}(34) \\
-.45^{* *} \\
(.15)\end{array}$ & $\begin{array}{c}(35) \\
-.51 * * \\
(.15)\end{array}$ & $\begin{array}{c}(35) \\
-.53 * * \\
(.15)\end{array}$ \\
\hline Marital Status & $\begin{array}{l}-.15 \\
(.29) \\
\end{array}$ & $\begin{array}{l}-.10 \\
(.30)\end{array}$ & $\begin{array}{l}-.07 \\
(.30)\end{array}$ \\
\hline Number of Children & $\begin{array}{l}.29 * \\
(.14)\end{array}$ & $\begin{array}{l}.29^{*} \\
(.14)\end{array}$ & $\begin{array}{l}.28^{*} \\
(.14)\end{array}$ \\
\hline Faculty / Staff & $\begin{array}{c}1.14 * * \\
(.24)\end{array}$ & $\begin{array}{l}1.12 * * \\
(.279)\end{array}$ & $\begin{array}{c}1.17 * * \\
(.25)\end{array}$ \\
\hline Employee Gender & & $\begin{array}{c}.16 \\
(.27)\end{array}$ & $\begin{array}{c}.22 \\
(.28)\end{array}$ \\
\hline Perceived Competency & & $\begin{array}{l}.41 * * \\
(.13)\end{array}$ & $\begin{array}{c}.23 \\
(.16)\end{array}$ \\
\hline Gender x Competency & & & $\begin{array}{l}.62^{*} \\
(.30)\end{array}$ \\
\hline $\mathrm{N}$ & 343 & 343 & 343 \\
\hline Chi-Square & $41.0^{* *}$ & $51.12 * *$ & $55.52 * *$ \\
\hline DF & 6 & 8 & 9 \\
\hline Pseudo $\mathrm{R}^{2}$ & .11 & .14 & .15 \\
\hline
\end{tabular}

${ }^{* *} \mathrm{P}<0.01,{ }^{*} \mathrm{P}<0.05,{ }^{\dagger} \mathrm{P}<0.08$; Numbers in parenthesis represent standard error 
Table 5: Perceived Competency $x$ those working 10 years or more

\begin{tabular}{|c|c|c|c|}
\hline \multirow[t]{2}{*}{$\mathrm{DV}$} & \multicolumn{3}{|c|}{ Aspiration to Leadershin } \\
\hline & Model 1 & Model 2 & Model 3 \\
\hline Supervisor Gender & $\begin{array}{l}-.01 \\
(.29)\end{array}$ & $\begin{array}{c}.16 \\
(.30)\end{array}$ & $\begin{array}{c}.16 \\
(.31)\end{array}$ \\
\hline Ethnicity & $\begin{array}{l}-.37 \\
(.41)\end{array}$ & $\begin{array}{l}-.27 \\
(.42)\end{array}$ & $\begin{array}{l}-.27 \\
(.43)\end{array}$ \\
\hline Age & $\begin{array}{c}-.86 * * \\
(.21)\end{array}$ & $\begin{array}{c}-1.03 * * \\
(.23)\end{array}$ & $\begin{array}{c}-1.04 * * \\
(.23)\end{array}$ \\
\hline Marital Status & $\begin{array}{c}.27 \\
(.35)\end{array}$ & $\begin{array}{c}.27 \\
(.37)\end{array}$ & $\begin{array}{c}.35 \\
(.37)\end{array}$ \\
\hline Number of Children & $\begin{array}{l}-.03 \\
(.15)\end{array}$ & $\begin{array}{l}-.04 \\
(.16)\end{array}$ & $\begin{array}{l}-.03 \\
(.16)\end{array}$ \\
\hline Faculty / Staff & $\begin{array}{c}1.05^{* *} * \\
(.29)\end{array}$ & $\begin{array}{c}.81 * * \\
(.31)\end{array}$ & $\begin{array}{l}.83^{* *} \\
(.31)\end{array}$ \\
\hline Employee Gender & & $\begin{array}{l}-.57 \dagger \\
(.32)\end{array}$ & $\begin{array}{l}-.58^{\dagger} \\
(.32)\end{array}$ \\
\hline Perceived Competency & & $\begin{array}{l}.44 * * \\
(.15)\end{array}$ & $\begin{array}{l}.76 * * \\
(.22)\end{array}$ \\
\hline Gender x Competency & & & $\begin{array}{l}-.64 * \\
(.29)\end{array}$ \\
\hline $\mathrm{N}$ & 254 & 254 & 254 \\
\hline Chi-Square & $49.25 * *$ & $63.00 * *$ & $67.95 * *$ \\
\hline $\mathrm{DF}$ & 6 & 8 & 9 \\
\hline Pseudo $\mathrm{R}^{2}$ & .18 & .22 & .24 \\
\hline
\end{tabular}

${ }^{* *} \mathrm{P}<0.01,{ }^{*} \mathrm{P}<0.05,{ }^{\dagger} \mathrm{P}<0.08$; Numbers in parenthesis represent standard error 
Table 6: Perceived Negative Leadership $\mathrm{x}$ those working less than 10 years

\begin{tabular}{|c|c|c|c|}
\hline \multirow[t]{2}{*}{ DV } & \multicolumn{3}{|c|}{ Aspiration to Leadership } \\
\hline & Model 1 & Model 2 & Model 3 \\
\hline Supervisor Gender & $\begin{array}{l}-.03 \\
(.17)\end{array}$ & $\begin{array}{l}-.03 \\
(.18)\end{array}$ & $\begin{array}{l}-.04 \\
(.18)\end{array}$ \\
\hline Ethnicity & $\begin{array}{l}.26 \\
(.24)\end{array}$ & $\begin{array}{c}.39 \\
(.25)\end{array}$ & $\begin{array}{c}.36 \\
(.26)\end{array}$ \\
\hline Age & $\begin{array}{c}-.32 * * \\
(.10)\end{array}$ & $\begin{array}{c}-.40 * * \\
(.11)\end{array}$ & $\begin{array}{c}-.42^{* *} \\
(.11)\end{array}$ \\
\hline Marital Status & $\begin{array}{l}-.10 \\
(.21)\end{array}$ & $\begin{array}{l}-.02 \\
(.22)\end{array}$ & $\begin{array}{l}-.03 \\
(.22)\end{array}$ \\
\hline Number of Children & $\begin{array}{l}.21^{*} \\
(.10)\end{array}$ & $\begin{array}{l}.31^{* *} \\
(.11)\end{array}$ & $\begin{array}{l}.32 * * \\
(.11)\end{array}$ \\
\hline Faculty / Staff & $\begin{array}{c}1.10^{* *} \\
(.17)\end{array}$ & $\begin{array}{l}.87 * * \\
(.18)\end{array}$ & $\begin{array}{l}.85 * * \\
(.18) \\
\end{array}$ \\
\hline Employee Gender & & $\begin{array}{l}.27 \\
(.19)\end{array}$ & $\begin{array}{l}.10 \\
(.20)\end{array}$ \\
\hline Negatives of Leadership & & $\begin{array}{c}-.72 * * \\
(.10)\end{array}$ & $\begin{array}{c}-.58 * * \\
(.11)\end{array}$ \\
\hline Gender x Negatives of Leadership & & & $\begin{array}{l}-.54^{*} \\
(.23)\end{array}$ \\
\hline $\mathrm{N}$ & 683 & 683 & 683 \\
\hline Chi-Square & $62.78^{* *}$ & $124.36^{* *}$ & $130.43 * *$ \\
\hline DF & 6 & 8 & 9 \\
\hline Pseudo R ${ }^{2}$ & .09 & .17 & .17 \\
\hline
\end{tabular}

${ }^{* *} \mathrm{P}<0.01,{ }^{*} \mathrm{P}<0.05,{ }^{\top} \mathrm{P}<0.08$; Numbers in parenthesis represent stand ard error 
Table 7: Perceived Negative Leadership $\mathrm{x}$ those working 10 years or more

\begin{tabular}{|c|c|c|c|}
\hline \multirow[t]{2}{*}{ DV } & \multicolumn{3}{|c|}{ Aspiration to Leadership } \\
\hline & Model 1 & Model 2 & Model 3 \\
\hline Supervisor Gender & $\begin{array}{l}-.06 \\
. .19)\end{array}$ & $\begin{array}{l}-.05 \\
(.20)\end{array}$ & $\begin{array}{l}-.05 \\
. .20)\end{array}$ \\
\hline Ethnicity & $\begin{array}{c}-.77 * * \\
(.29)\end{array}$ & $\begin{array}{l}-.60^{*} \\
(.30)\end{array}$ & $\begin{array}{l}-.61^{*} \\
(.30)\end{array}$ \\
\hline Age & $\begin{array}{c}-.81 * * \\
(.14)\end{array}$ & $\begin{array}{l}-.91 * * \\
(.114)\end{array}$ & $\begin{array}{c}-.91 * * \\
(.14)\end{array}$ \\
\hline Marital Status & $\begin{array}{l}.08 \\
.(24)\end{array}$ & $\begin{array}{l}.27 \\
(.26)\end{array}$ & $\begin{array}{l}.27 \\
(.26)\end{array}$ \\
\hline Number of Children & $\begin{array}{l}.07 \\
(.10)\end{array}$ & $\begin{array}{l}.06 \\
(.11)\end{array}$ & $\begin{array}{l}.06 \\
(.11)\end{array}$ \\
\hline Faculty / Staff & $\begin{array}{l}1.0^{* * *} \\
(.19)\end{array}$ & $\begin{array}{l}.64 * \\
(.21)\end{array}$ & $\begin{array}{l}.64^{*} \\
(.21)\end{array}$ \\
\hline Employee Gender & & $\begin{array}{l}-.29 \\
(.21)\end{array}$ & $\begin{array}{l}-.28 \\
(.21)\end{array}$ \\
\hline Negatives of Leadership & & $\begin{array}{c}-.70 * * \\
(.11)\end{array}$ & $\begin{array}{c}-.67 * * \\
(.14)\end{array}$ \\
\hline $\begin{array}{l}\text { Gender x Negatives of } \\
\text { Leadership }\end{array}$ & & & $\begin{array}{l}-.09 \\
(.22)\end{array}$ \\
\hline $\mathrm{N}$ & 553 & 553 & 553 \\
\hline Chi-Square & $97.81 * *$ & $144.68 * *$ & $144.83 * *$ \\
\hline DF & 6 & 8 & 9 \\
\hline Pseudo $\mathrm{R}^{2}$ & .16 & .23 & .23 \\
\hline
\end{tabular}

${ }^{* *} \mathrm{P}<0.01,{ }^{*} \mathrm{P}<0.05,{ }^{\dagger} \mathrm{P}<0.08$; Numbers in parenthesis represent standard error 